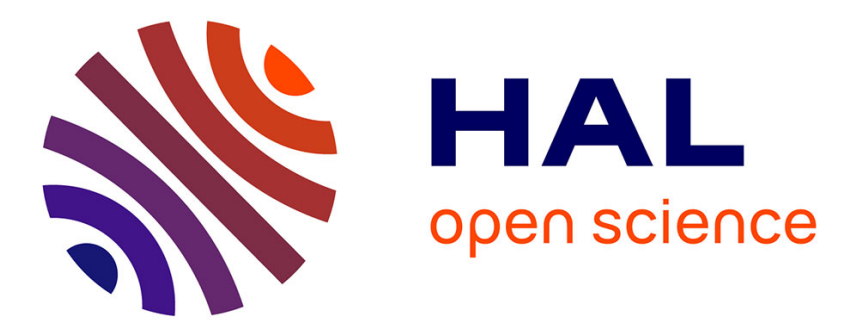

\title{
Phorbol 12-myristate 13-acetate inhibits FRO anaplastic human thyroid cancer cell proliferation by inducing cell cycle arrest in G1/S phase: Evidence for an effect mediated by $\mathrm{PKC} \delta$
}

Emad Afrasiabi, Janiina Ahlgren, Nina Bergelin, Kid Törnquist

\section{To cite this version:}

Emad Afrasiabi, Janiina Ahlgren, Nina Bergelin, Kid Törnquist. Phorbol 12-myristate 13-acetate inhibits FRO anaplastic human thyroid cancer cell proliferation by inducing cell cycle arrest in G1/S phase: Evidence for an effect mediated by $\operatorname{PKC} \delta$. Molecular and Cellular Endocrinology, 2008, 292 (1-2), pp.26. 10.1016/j.mce.2008.04.018 . hal-00532023

\section{HAL Id: hal-00532023 \\ https://hal.science/hal-00532023}

Submitted on 4 Nov 2010

HAL is a multi-disciplinary open access archive for the deposit and dissemination of scientific research documents, whether they are published or not. The documents may come from teaching and research institutions in France or abroad, or from public or private research centers.
L'archive ouverte pluridisciplinaire HAL, est destinée au dépôt et à la diffusion de documents scientifiques de niveau recherche, publiés ou non, émanant des établissements d'enseignement et de recherche français ou étrangers, des laboratoires publics ou privés. 


\section{Accepted Manuscript}

Title: Phorbol 12-myristate 13-acetate inhibits FRO anaplastic human thyroid cancer cell proliferation by inducing cell cycle arrest in G1/S phase: Evidence for an effect mediated by PKC $\delta$

Authors: Emad Afrasiabi, Janiina Ahlgren, Nina Bergelin, Kid Törnquist

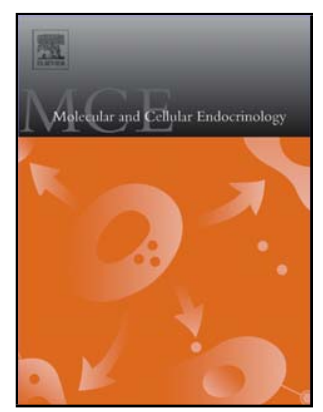

PII: S0303-7207(08)00201-3

DOI: doi:10.1016/j.mce.2008.04.018

Reference: MCE 6871

To appear in: Molecular and Cellular Endocrinology

Received date: 13-3-2008

Revised date: $30-4-2008$

Accepted date: $30-4-2008$

Please cite this article as: Afrasiabi, E., Ahlgren, J., Bergelin, N., Törnquist, K., Phorbol 12-myristate 13-acetate inhibits FRO anaplastic human thyroid cancer cell proliferation by inducing cell cycle arrest in G1/S phase: Evidence for an effect mediated by PKC $\delta$, Molecular and Cellular Endocrinology (2007), doi:10.1016/j.mce.2008.04.018

This is a PDF file of an unedited manuscript that has been accepted for publication. As a service to our customers we are providing this early version of the manuscript. The manuscript will undergo copyediting, typesetting, and review of the resulting proof before it is published in its final form. Please note that during the production process errors may be discovered which could affect the content, and all legal disclaimers that apply to the journal pertain. 


\section{Phorbol 12-myristate 13-acetate inhibits FRO anaplastic}

3 human thyroid cancer cell proliferation by inducing cell

4 cycle arrest in G1/S phase: Evidence for an effect mediated

5 by PKC $\delta$.

6

7

8

9

10

11 From the ${ }^{1}$ Department of Biology, Åbo Akademi University, BioCity, Artillerigatan 6, 20520

12 Turku, Finland, ${ }^{2}$ Turku Graduate School of Biomedical Sciences, and ${ }^{3}$ The Minerva

13 Foundation Institute for Medical Research, Biomedicum Helsinki, 00290 Helsinki, Finland.

14

15

16

17

18

19

20

21

22

23

24

Correspondence should be addressed to Dr. Kid Törnquist, Department of Biology, Åbo Akademi University, BioCity, Artillerigatan 6, 20520 Turku, Finland. Tel: 02-2154263. Email: ktornqvi@,abo.fi.

Running title: Antiproliferative effects of PMA in FRO cells. 


\section{Abstract}

26 Phorbol 12-myristate 13-acetate (PMA) is known to affect a variety of cellular processes, 27 including cell proliferation, differentiation, and migration. PMA has been shown to promote 28 antiproliferative and antimigratory effects in many types of cancer cells. Our findings show 29 that PMA induced a strong antiproliferative effect in two anaplastic (FRO and ARO) and one 30 follicular (ML-1) thyroid cancer cell lines, and increased the fraction of FRO cells in G1 phase of the cell cycle. The fractions in the S- and G2 phases were decreased. Moreover, PMA evoked a significant increase in the levels of the cell cycle regulators $\mathrm{p} 21^{\mathrm{Waf} 1 / \mathrm{Cip} 1}$ and $\mathrm{p} 27^{\mathrm{Kip} 1}$. The levels of cyclin D3 and the cyclin dependent kinases cdk4 and cdk6 decreased, as did the phosphorylation of the Rb-protein. PMA did not induce apoptosis. PMA stimulated the translocation of protein kinase $\mathrm{C}(\mathrm{PKC}) \alpha,-\beta \mathrm{I}$ and $-\delta$ isoforms to the cell membrane. PKC $\delta$ small interfering RNA attenuated the PMA-induced antiproliferative effect and prevented the upregulation of $\mathrm{p} 21^{\text {Wafl/Cip1 }}$ and $\mathrm{p} 27^{\mathrm{Kip} 1}$. Prolonged stimulation with PMA decreased the phosphorylation of mitogen-activated protein (MAP) kinase. PMA also decreased the phosphorylation of Akt and evoked a biphasic change in the phosphorylation of the forkhead box class-O protein (FOXO): an increase in phosphorylation, followed by a dephosphorylation. In addition, PMA inhibited FRO, ARO and ML-1 cell migration toward serum. The inactive phorbol ester analog 4 $\alpha$-phorbol and the diacylglycerol analog 1,2dioctanoyl-sn-glycerol were without an effect on proliferation and migration. The results indicate that PMA is an effective inhibitor of thyroid cancer cell proliferation and migration by a mechanism involving PKC-MAP kinase/Akt and FOXO signaling.

Key words: thyroid, cancer, phorbol esters, cell cycle, protein kinase C. 


\section{Introduction}

Protein kinase $\mathrm{C}(\mathrm{PKC})$ is a family of serine-threonine kinases that regulate many cellular processes including proliferation and survival. The numerous isotypes of PKC exert important functions in the regulation of the cell cycle and intracellular signal transduction (Nishizuka, 1986; Levesque and Siard, 1995). PKC-mediated signal transduction pathways convert extracellular stimulation into a variety of cellular functions (Griner and Kazanietz, 2007). Phorbol 12-myristate 13-acetate (PMA) is a natural compound originally isolated from the seed oil of the plant Croton tiglium and is a well known activator of PKC (Griner and Kazanietz, 2007). The effect of PMA varies depending on cell type, the relative expression and distribution of different phorbol ester receptors and their downstream effectors (Nakagawa et al., 2005). In most normal cell types investigated, activation of PKC by PMA enhances proliferation, while the proliferation of different cancer cell lines is inhibited upon stimulation with PMA (Griner and Kazanietz, 2007).

Activation of PKC by PMA involves acute translocation of the PKC isoforms (PKCs) to the plasma membrane, which occurs within a few minutes after stimulation (Newton, 2001). The endogenous analogue of phorbol esters is diacylglycerol (DAG). Although the activation of PKC by DAG is a transient event due to its fast metabolism, the action of phorbol esters is sustained, leading to prolonged activation of PKCs (Blumberg et al., 1983).

The regulation of proliferation is a complicated process and is regulated by different cyclin-dependent kinases (cdks), which are activated by binding to different types of cyclin forming cyclin/cdk complexes to control the cell cycle (Damia and Broggini, 2004). During the G1 phase the cyclin-dependent kinase inhibitors p21 $1^{\mathrm{Waf} 1 / \mathrm{Cip} 1}$ and $\mathrm{p} 27^{\mathrm{Kip} 1}$ negatively regulate the activity of the cyclin/cdk complexes (Sinibaldi et al., 2000). Another critical effector in the G1 phase is the retinoblastoma (Rb)-protein (Dyson, 1998, Nevins, 1998). 
The phosphoinositide-3 kinase (PI-3 kinase)/Akt pathway is also an important regulator

74 of proliferation and has been implicated in thyroid tumorigenesis and particularly in the 75 inactivation of $\mathrm{p} 21^{\text {Wafl/Cip } 1}$ (Liang and Singerland 2003; Shinohara et al., 2007). Furthermore the forkhead box class-O (FOXO) transcription factors play critical roles in a variety of physiological and pathological processes including cancer and are subject to negative regulation by the PI-3 kinase/Akt signal transduction pathway (Arden, 2006; Myatt and Lam, 2007). FOXO can also upregulate p27 and p21 gene expression (Medema et al., 2000; Dehan and Pagano, 2005).

$\mathrm{PKC}$ is involved in the control of the mitogen-activated protein (MAP) kinase pathway, which is responsible for controlling of diverse cellular responses, such as proliferation, differentiation and cell death (Pettersson et al., 2004). In NPA thyroid cancer cells, PKC $\delta$ activation has been shown to induce growth arrest by a mechanism dependent on MAP kinase (Koike et al., 2006). Recently we have shown that the MAP kinase pathway is an important component in the regulation of thyroid cancer cell proliferation (Afrasiabi et al., 2007) and in our previous studies we were able to show some implications for the role of PKC in thyroid cancer cell signaling (Afrasiabi et al., 2006). In addition to regulating proliferation, cell migration is another important biological process which is regulated by PKC (Nishizuka 1988). While PKC $\delta$ inhibition has been shown to limit the migration of prostate cancer cells (Kharait et al., 2006), PMA has been indicated as a negative regulator of breast cancer cells migration by targeting PKC $\alpha$ (Gauthier et al., 2003).

Previous studies have shown that by activation of PKC in dog thyroid cells, or in rat FRTL-5 thyroid cells, PMA promotes cell proliferation (Roger et al., 1986; Takada et al., 1988; Lombardi et al., 1988). In human cells in culture, a biphasic effect is observed: in shortterm cultures, PMA inhibits proliferation, but in cells grown for longer periods, PMA 
97 stimulates proliferation (Kraiem et al., 1995). However, in thyroid cancer cells, activation of

98 PKC with PMA seems to have an inhibitory effect on proliferation (Koike et al., 2006).

99 The aim of the present study is to clarify the role of PKC in the growth and survival of 100 anaplastic thyroid FRO cancer cells. We thus investigated the effect of PMA on proliferation 101 and the cell cycle regulatory proteins, and on cell migration. Our investigation revealed that

102 PMA is a potent inhibitor of both proliferation and migration in thyroid cancer cells.

\section{Materials and methods}

105 Materials. RPMI 1640 medium (without L-glutamine) and non-essential aminoacids were

106 from Cambrex (Verviers, Belgium). L-glutamine, foetal bovine serum (FBS), penicillin and 107 streptomycin were from GIBCO (Grand Island, NY, USA). DMEM (Dulbecco's modified 108 Eagel's medium), phorbol 12-myristate 13-acetate (PMA), 4 $\alpha$-phorbol, DOG and propidium 109 iodide were from Sigma (St.Louis, MO, USA). GF 109203X, calphostin C, rottlerin, PD 110 98059, UO 126, LY 294002 and GÖ 6976, ALLM and ALLN were from Calbiochem 111 (Darmstadt, Germany). Celltiter 96 solution cell proliferation assay was purchased from

112 Promega corporation (Madison, WI, USA). Human Collagen type I was from Becton

113 Dickinson Biosciences (Bedford, MA, USA). Primary antibodies against p2 $1^{\text {waf1/cip1 }}$, p2 $7^{\text {kip1 }}$, 114 cyclin D1, cyclin D2, cyclin D3, cyclin E, cdk2, cdk4, cdk6, Rb, phospho-Rb (Ser-780), 115 phospho-Rb (Ser-795), p44/42 MAP kinase, phospho-p44/42 MAP kinase (Thr-202/Tyr-204), 116 Akt, phospho-Akt (Ser-473), phospho-Akt (Thr-308), FoxO1, phospho-FoxO1 (Ser-256), 117 phospho-FoxO1 (Thr-24) and ß-actin were obtained from Cell Signaling Technology 118 (Danvers, MA, USA). Isoenzyme-specific PKC antibodies were from Santa Cruz 119 Biotechnology (Santa Cruz, CA, USA). PKC $\beta I$ specific inhibitory peptide (KIBI31-1) was 120 obtained from KAI Pharmaceuticals (South San Fransisco, CA, USA). The secondary 
121 antibodies used were horseradish peroxidase-conjugated anti-mouse and anti-rabbit antibodies

122 (Sigma). Culture dishes were purchased from Falcon Plastics (Becton, NJ, USA).

123

124 Cell culture. The FRO and ARO human anaplastic thyroid cancer cell lines were a generous

125 gift from Dr. James Fagin (Memorial Sloan-Kettering Cancer Center, NY, USA). The ML-1

126 follicular thyroid cancer cells were provided generously by Dr. Johann Schönberger

127 (University of Rosenburg, Germany). FRO and ARO cells were cultured in RPMI 1640

128 medium and ML-1 cells were cultured in DMEM medium supplemented with 10\% FBS, 1\%

129 non-essential aminoacids, $2 \mathrm{mM} \mathrm{L}$ - glutamine, $50 \mathrm{U} / \mathrm{ml}$ penicillin and $50 \mu \mathrm{g} / \mathrm{ml}$ streptomycin

130 and were grown in a water-saturated atmosphere containing $5 \% \mathrm{CO}_{2}$ and $95 \%$ air at $37{ }^{\circ} \mathrm{C}$.

131 The day before an experiment the medium was removed and replaced with RPMI containing

$1325 \%$ dextran-treated-charcoal-stripped FBS.

133

$134{ }^{3}$ H-thymidine incorporation assay. Cell proliferation was determined using ${ }^{3} \mathrm{H}$-thymidine 135 incorporation (Amersham, Buckinghamshire, UK). For the assay 50000 cells were cultured 136 for $48 \mathrm{~h}$ on $35-\mathrm{mm}$ plates in a water-saturated atmosphere containing $5 \% \mathrm{CO}_{2}$ and $95 \%$ air at

$13737^{\circ} \mathrm{C}$ followed by $24 \mathrm{~h}$ of treatment with the indicated concentrations of PMA. At the day of

138 the experiment, the cultures were pulsed with ${ }^{3} \mathrm{H}$-thymidine $(0.4 \mu \mathrm{Ci} / \mathrm{ml})$ for $4 \mathrm{~h}$ of

139 incubation. Cells were washed three times with ice cold PBS followed by a $10 \mathrm{~min}$

140 incubation with $5 \%$ perchloric acid and another 10 min with $0.1 \mathrm{~N} \mathrm{NaOH}$. Cells were

141 harvested and radioactivity was counted using a Wallac 1410 liquid scintillation counter

142 (Wallac OY, Turku, Finland). ${ }^{3} \mathrm{H}$-thymidine uptake was expressed as mean counts per minute

$143(\mathrm{cpm})$ of triplicate samples. The results were confirmed by cell counting using trypan blue. 
145 Celltiter assay. The cells (10 000 cells/well), seeded into 96-well plates for $24 \mathrm{~h}$, were

146 incubated with different concentrations of PMA for $1-20 \mathrm{~h}$ at $37{ }^{\circ} \mathrm{C}$ in $5 \% \mathrm{CO}_{2}$ and $95 \%$ air.

147 After adding $100 \mu \mathrm{l} /$ well of celltiter 96 reagent solution $(5 \mathrm{mg} / \mathrm{ml})$, the plates were incubated

148 for another $2 \mathrm{~h}$. Optical density was determined at $540 \mathrm{~nm}$ using the Viktor fluorescence

149 analyser (PerkinElmer Life Sciences, Turku, Finland).

151 Cell migration assay. Migration experiments were performed on $6.5 \mathrm{~mm}$-diameter Transwell

152 (Corning Costar, Bodenheim, Germany) chambers with $8 \mu \mathrm{M}$ pore size. The filters were 153 coated with collagen I $\left(5 \mu \mathrm{g} / \mathrm{cm}^{2}\right)$ and then placed into the lower chamber. Lipid-stripped FBS

154 was placed in the lower chamber as a chemoattractant. Cells were harvested and diluted with 155 RPMI medium containing 0.1\% BSA, 100000 cells were added to the upper chamber and 156 treated as indicated. The chambers were incubated in a humidified incubator at $37{ }^{\circ} \mathrm{C}$ in $5 \%$

$157 \mathrm{CO}_{2} / 95 \%$ air for $6 \mathrm{~h}$. The cells that traversed the filter and spread on the lower surface of the

158 filter were fixed with $2 \%$ paraformaldahyde in PBS for $10 \mathrm{~min}$, and stained with $0.1 \%$ crystal 159 violet in $20 \%$ methanol for $5 \mathrm{~min}$. The membranes were rinsed and allowed to dry. 160 Nonmigratory cells on the upper membrane surface were removed with a cotton swab. The 161 number of migratory cells/membrane was counted with 40x magnification in eight 162 microscopic fields in a straight line bisecting the membrane.

163

164 Western blot analysis. FRO cells were cultured in 5\% lipid stripped FBS medium for 1 day 165 and stimulated with $100 \mathrm{nM}$ PMA for the indicated time. After stimulation, FRO cells were 166 washed 3 times with ice-cold PBS and lysed in cell lysis buffer [10mM Tris (pH 7.7), 150 $167 \mathrm{mM} \mathrm{NaCl}, 7 \mathrm{mM}$ EDTA, 0.5\% NP-40, $0.2 \mathrm{mM}$ PMSF (phenylmethylsulfonyl fluoride) and $1680.5 \mu \mathrm{g} / \mathrm{ml}$ leupeptin], the lysate was centrifuged at $13000 \mathrm{rpm}$ for $15 \mathrm{~min}$ at $+4{ }^{\circ} \mathrm{C}$ and the 169 supernatant was collected. The protein concentration was determined using the $\mathrm{BCA}^{\mathrm{TM}}$ Protein 
170 Assay Kit (Pierce, Rockford, IL, USA). The samples were then stored at $-20{ }^{\circ} \mathrm{C}$. Samples $(15$

$171 \mu \mathrm{g}$ of protein/sample) were subjected to SDS/PAGE (10\% polyacrylamide). The proteins

172 were transferred onto nitrocellulose membrane (Schleicher \& Schuell, Dassel, Germany) by

173 wet-blotting. Western blot analysis was performed using specific antibodies to the indicated

174 proteins. The secondary antibodies used were horseradish peroxidase-conjugated anti-mouse

175 and anti-rabbit antibodies. The proteins were detected by enhanced chemiluminescence. For

176 loading controls, membranes were washed with $1 \mathrm{M}$ Tris $(\mathrm{pH} 7.6)$, stripped for 20 min in 0.1

$177 \mathrm{M}$ glycin ( $\mathrm{pH}$ 2.5) and subjected to anti ß-actin antibody. Densitometric analysis was

178 performed using ImageJ program for image analysis (NIH, Bethesda, MD, USA) and results

179 were corrected for protein loading by normalization for ß-actin expression.

180

181 Western blot of PKC isoenzymes. Cells were harvested in Hepes-buffered salt solution

182 (HBSS; $118 \mathrm{mM} \mathrm{NaCl}, 4.6 \mathrm{mM} \mathrm{KCl}, 1 \mathrm{mM} \mathrm{CaCl}, 10 \mathrm{mM}$ glucose and $20 \mathrm{mM}$ Hepes, $\mathrm{pH}$

183 7.4) lacking calcium and containing $0.02 \%$ EDTA and were subsequently washed twice in

184 HBSS. After stimulation by $100 \mathrm{nM}$ PMA for the indicated time at room temperature,

185 cytosolic and particulate fractions were prepared as described by Kass et al., 1989. Proteins

186 were subjected to PKC-isoform specific antibodies according to the western blot protocol

187 mentioned above.

188

189 Fluorescence-activated cell sorting (FACS) analysis. This analysis was based on the

190 measurement of the DNA content of nuclei labelled with propidium iodide. For cell cycle

191 evaluation, cells were treated as for the proliferation experiments, washed with ice-cold PBS

192 and incubated with propidium iodide $(0.05 \% \mathrm{mg} / \mathrm{ml}$ in $3.8 \mu \mathrm{M}$ sodium citrate, $0.1 \%$ Triton X-

193 100) for $15 \mathrm{~min}$ at room temperature in the dark. Cells then were subjected to FACS and

194 analysis of the cell cycle was evaluated using FACSCalibur flow cytometer (Becton- 
195 Dickinson Biosciences, San Jose, CA, USA). Data were analyzed using the Cell Quest Pro 196 software package (BD Biosciences).

197

Transfection with small interference RNA (siRNA). FRO cells (100 000 cells/35 mm dish)

were seeded in penicillin/streptomycin-free medium for $24 \mathrm{~h}$ and subsequently transfected with a negative control, or with double-stranded siRNAs (dsRNAs) purchased from Dharmacon Inc. (Dallas, TX, USA). The following targeting sequences were used: PKC $\alpha$ (AATCCTTGTCCAAGGAGGCTG) and PKC $\delta$ (AACCATGAGTTTATCGCCACC). dsRNAs were transfected into FRO cells using METAFECTENE ${ }^{\mathrm{TM}}$ PRO (Biontex, Martinsried/Planegg, Germany) following the protocol provided by the manufacturer. $48 \mathrm{~h}$ after transfection, cells were stimulated with PMA in 5\% lipid-stripped FBS medium.

Western blot and ${ }^{3} \mathrm{H}$-thymidine incorporation experiments were carried out as described 207 previously.

Microscopy. FRO cells were grown on $35-\mathrm{mm}$ plates and treated with $100 \mathrm{nM}$ PMA or vehicle for the indicated time, in low FBS containing medium. Light microscopic monitoring 211 were carried out using the Axiovert 35 (Carl Zeiss, Oberkochen, Germany) microscope and 212 analysed by the "Scion" image-processing program (Scion Corporation, MD, USA).

Statistics. Results are expressed as means \pm SEM. Analysis of statistical significance was 215 performed using Student's $t$ test for paired observations. Three or more means were tested 216 using one-way ANOVA and Dunnett's post hoc test. Curve fitting and statistical analyses 217 were made using the Prism 3.03 program (GraphPad, San Diego, CA, USA). A P-value less 218 than 0.05 was considered significant. 
220

221

222

223

224

225

226

227

228

229

230

231

232

233

234

235

236

237

\section{Results}

Effects of PMA on thyroid cancer cell proliferation. In FRO thyroid cancer cells, PMA decreased the incorporation of ${ }^{3} \mathrm{H}$-thymidine in a concentration- and time-dependent manner (Fig. 1A \& 1B). In ARO cells, a substantially higher concentration of PMA was needed to decrease the incorporation of ${ }^{3} \mathrm{H}$-thymidine (Fig. 1A). A PMA-evoked decrease in the proliferation of FRO and ML-1 cells was also seen with the celltiter assay (Fig. 1C). As some FRO cells detached after PMA treatment, we verified the results by counting all cells in a cell dish. In these experiments we observed an increase in the cell number in control dishes, whereas no increase was observed in cells incubated with $100 \mathrm{nM}$ PMA for $24 \mathrm{~h}$ (Fig. 1 D). In all these experiments neither the phorbol ester analog $4 \alpha$-phorbol $(1 \mu \mathrm{M})$ nor the diacylglycerol (DAG) analog 1,2-dioctanoyl-sn-glycerol (DOG, $10 \mu \mathrm{M})$ could inhibit FRO cell proliferation. In order to clarify the mechanism of action of the antiproliferative effect of PMA, we preincubated the cells for $1 \mathrm{~h}$ with the PKC inhibitors [GF 109203X (10 $\mu \mathrm{M})$, calphostin $\mathrm{C}(100 \mathrm{nM})$, rottlerin $(10 \mu \mathrm{M})$ or GÖ $6976(1 \mu \mathrm{M})]$, the MAP/ERK1/2 kinase inhibitors [PD $98059(10 \mu \mathrm{M})$ or U $0126(10 \mu \mathrm{M})]$, the calcium channel blocker 2APB (50 $\mu \mathrm{M})$, the calpain inhibitors $[\operatorname{ALLN}(50 \mu \mathrm{M})$ or ALLM $(50 \mu \mathrm{M})]$ or the PI-3 kinase inhibitor LY $294002(10 \mu \mathrm{M})$. However, all these compounds per se decreased substantially FRO cell proliferation, and were, in addition, unable to attenuate the PMA-induced effect on cell proliferation (data not shown). Thus, the use of these inhibitors made it impossible to draw any conclusions on the mechanisms mediating the antiproliferative effect of PMA

When cells treated with PMA for $24 \mathrm{~h}$ were washed and replated, the cells continued to grow with almost the same efficiency as control cells (Fig 1E). We also investigated the effects of PMA on FRO cell morphology. Treatment with PMA resulted in a rapid (within 15 min) rounding of the cells (Fig. 1F). 
Effects of PMA on FRO, ARO and ML-1 cell migration. We next studied the migration of FRO, ARO and ML-1 cells and we noticed that PMA reduced the migration of cells in a different concentration profile when lipid-stripped FBS was used as a chemoattractant. The inhibitory concentrations were higher compared to those needed to attenuate the proliferation and neither the phorbol ester analog, $4 \alpha$-phorbol nor DOG could inhibit FRO cell migration toward serum (Fig. 2A \& 2B).

Efects of PMA on the cell cycle and the expression levels of cell cycle regulatory proteins. To further understand by which mechanism PMA blocked cell proliferation, we next determined the cell cycle profile of FRO cells after the treatment with PMA. Interestingly, PMA induced a significant change in the distribution of the cells: an increase of the cell population in the G1 phase and a decrease in the $\mathrm{S}$ phase of the cell cycle (Fig. 3A \& Table 1). We were unable to detect any apoptotic cells in this assay. In addition, neither $4 \alpha$-phorbol nor DOG induced significant changes in the cell cycle (Table 1). To clarify the mechanism by which PMA induced cell cycle changes, we examined the possible roles of $\mathrm{p} 27^{\mathrm{kip} 1}$ and $\mathrm{p} 21^{\mathrm{waf1} / \mathrm{cip} 1}$, two oncogenes linked to the regulation of the cell cycle (Damia and Broggini, 2004), and also cyclin D1, cyclin D2, cyclin D3, cyclin E, cdk2, cdk4, cdk6 and the Rb-protein, all of which are of importance in the regulation of the cell cycle in the G1 phase. The levels of $\mathrm{p} 21^{\text {wafl/cip } 1}$ and $\mathrm{p} 27^{\mathrm{kip} 1}$ were significantly increased, compared with control cells. Additionally, treatment of the cells with PMA could not affect the expression levels of cyclin D1, cyclin D2, cyclin E and cdk2, but significantly decreased the levels of cyclin D3, cdk4, cdk6 and the levels of Rbprotein phosphorylation at Ser-780 and Ser-795 (Fig. 3B \& Table 2).

Effects of PMA on different PKC isoforms in FRO cells. We next investigated the effects of PMA on the translocation of different PKC isoforms between the cell membrane and the 
270

271

272

273

274

275

276

277

278

279

280

281

282

283

284

285

286

287

288

289

290

291

292

293

cytosol. Previously we have shown that FRO cells express four different isoforms (i.e. $\alpha, \beta I$, $\delta, \zeta$ ) of PKC (Afrasiabi et al., 2006). Here we show that stimulating the cells with $100 \mathrm{nM}$ PMA resulted in a rapid translocation of $\mathrm{PKC} \alpha, \mathrm{PKC} \beta \mathrm{I}$ and $\mathrm{PKC} \delta$ from the cytosolic to the particulate fractions (Fig. 4). Densitometric analysis showed that the relative distribution of PKC $\alpha$ to the particulate fraction of was elevated by $98.0 \pm 7.1 \%$ after $10 \mathrm{~min}$ of stimulation with PMA $(\mathrm{P}<0.05)$, although the distribution to the cytosolic fraction was not changed. The distribution of PKC $\beta \mathrm{I}$ in the cytosolic fraction was decreased by $86.1 \pm 5.5 \%(\mathrm{P}<0.05)$, whereas the distribution to the particulate fraction was increased by $79.6 \pm 12.7 \%(\mathrm{P}<0.05)$ after $10 \mathrm{~min}$. The distribution of PKC $\delta$ was also altered; the cytosolic fraction was reduced by $72.2 \pm 14 \%(\mathrm{P}<0.05)$ and the particulate fraction increased by $91.1 \pm 4.9 \%(\mathrm{P}<0.05)$, after 10 min of stimulation. PMA was without a significant effect on the distribution of the PKC $\zeta$ isoform.

The inhibitory effects of PMA in FRO cells proliferation is mediated by PKC $\delta$. We investigated further which PKC isofrom mediated the effect of PMA. Preincubation of the cells with a cell-permeant inhibitory peptide against PKC $\beta$ I did not attenuate the effect of PMA on proliferation, although the distribution of PKC $\beta$ I to the particulate fraction was potently attenuated (data not shown). We next transfected the FRO cells with a negative control, or with specific dsRNAs for PKC $\alpha$ and $\mathrm{PKC} \delta$ (Fig.5 A\&B), since these isoformes are known to be responsible for growth inhibitory properties in different cell types (Nakagawa et al., 2005). As it is shown in Fig. 5C, the inhibitory effects of PMA on FRO cell proliferation was reduced by more than $50 \%$ in cells transfected with $\mathrm{PKC} \delta$ siRNA compared to PKC $\alpha$ depleted and control cells, indicating that $\mathrm{PKC} \delta$ mediates the anti-proliferative effect of PMA in FRO cells. Moreover, when cells were transfected with PKC $\delta$ siRNA, PMA was not able to 
294 upregulate neither $\mathrm{p} 27^{\mathrm{kip} 1}$ nor $\mathrm{p} 21^{\mathrm{waf} 1 / \mathrm{cip} 1}$, whereas an increase was still seen in PKC $\alpha$ 295 depleted and control cells (Fig. 5D \& Table 3).

296 Effects of PMA on the phosphorylation of MAP kinase, Akt and FOXO1. Upon short 297 stimulation (0-60 min) of FRO cells with PMA, the phosphorylation of MAP kinase at Thr298 202/Tyr-204 increased, but decreased significantly after 24 h of treatment (Fig. 6A\&B). PMA 299 was without an effect on the total amount of MAP kinase in the cells. Furthermore, the 300 phosphorylation of Akt at Thr-308 was decreased after a 30-min stimulation (Fig. 6C).

301 Finally, PMA stimulation resulted in an increase of the phosphorylation levels of FOXO1 at 302 Ser-256 after a 30-min stimulation, whereas the phosphorylation was decreased after $24 \mathrm{~h}$ of 303 stimulation (Fig. 6 D\&E). We could not observe any PMA-evoked effects on the 304 phosphorylation of FOXO1 at Thr-24, either at $30 \mathrm{~min}$ or $24 \mathrm{~h}$ of stimulation and were unable 305 to detect an effect of PMA on the total amount of FOXO1 after either a 30 min- or a $24 \mathrm{~h}$ 306 stimulation (data not shown).

\section{Discussion}

309 In the present study we show that PMA is an inhibitor of FRO thyroid cancer cell 310 proliferation and migration. Our results suggest that the antiproliferative effect of PMA was 311 due to an arrest of the cells in the G1-S phase of the cell cycle. This arrest was the result of a

$312 \mathrm{PKC} \delta$-mediated upregulation of the cdk inhibitory proteins $\mathrm{p} 21^{\text {wafl/cip } 1}$ and $\mathrm{p} 27^{\mathrm{kip} 1}$ and a 313 downregulation of cyclin D3, cdk4, and cdk6. In addition, we observed a susbstantial

314 hypophosphorylation of the Rb-protein. Furthermore, our results suggest that these effects are, 315 at least in part, mediated through an inhibition of the PI-3 kinase/Akt-FOXO and MAP kinase 316 pathways.

317 Previous reports have established that PMA is a potential antiproliferative agent in 318 different cancer cell lines, including NPA thyroid cancer cells (Frey et al., 2000; Nakagawa et 
319

320

321

322

323

324

325

326

327

328

329

330

331

332

333

334

335

336

337

338

339

340

341

342

343

al., 2005; Koike et al., 2006; Martin et al., 2007). In these investigations, PKC $\alpha, \delta$ and $\varepsilon$ have been shown to mediate the effect of PMA. In our experiments, the translocation of PKC $\alpha, \beta I$ and $\delta$ to the cell membrane indicated a possible role for these isoforms in PMA induced signaling. Using a specific PKC $\beta$ I inhibitory peptide, and siRNA against PKC $\alpha$ and PKC $\delta$ we showed, that in FRO cells, PKC $\delta$ is responsible for the antiproliferative effect of PMA. Although PKC $\delta$ seems to evoke a downregulation of cyclins D1 and E in several other cancer cell types (Nakagawa et al., 2005; Cerda et al., 2006; Koike et al., 2006), we could not observe any effects of PMA on cyclin D1, D2 or E. However, other investigations have stressed the importance of cyclin D3 in PI-3 kinase/Akt evoked G1-S transition (Spofford et al., 2006). Our results support the conclusion that the PI-3 kinase/Akt pathway is of importance in regulating cyclin D3. Thus, the cell signaling pathways leading to inhibition of proliferation are at least to some degree cell type specific.

Akt is a central signaling molecule in the regulation of cell proliferation and migration.

Akt is constitutively activated in human cancers, including thyroid cancer, leading to the suppression of $\mathrm{p} 21^{\mathrm{wafl} / \mathrm{cip} 1}$ and $\mathrm{p} 27^{\mathrm{kip} 1}$ and facilitating progression through the G1-S phase of the cell cycle (Liang and Sligerland, 2003; Shinohara et al., 2007). Thus, one mechanism by which PMA exerts its effect seems to be through inhibition of Akt, resulting in upregulation of $\mathrm{p} 21^{\mathrm{waf} 1 / \mathrm{cip} 1}$ and $\mathrm{p} 27^{\mathrm{kip} 1}$ and arrest of the cells in the G1-S phase. Furthermore, Akt regulates the phosphorylation of the forkhead family transcription factors (FOXO) leading to their nuclear exclusion and thus inhibition of FOXO-mediated gene expression (Brunet et al. 1999). As the promotor of $\mathrm{p} 27^{\mathrm{kip} 1}$ contains multiple putative FOXO binding sites and as FOXO can upregulate p27 gene expression (Medema et al., 2000), it is feasible to assume that the PMA-evoked inhibition of Akt resulted in a FOXO-mediated upregulation of $\mathrm{p} 21^{\text {wafl/cip1 }}$ and $\mathrm{p} 27^{\mathrm{kip} 1}$. Previous studies have also suggested that $\mathrm{p} 21^{\mathrm{waf} 1 / \mathrm{cip} 1}$ and $\mathrm{p} 27^{\mathrm{kip} 1}$ are upregulated by PKC $\delta$ in e.g. prostate (Nagakawa et al., 2005), colon (Perletti et al., 2004), and thyroid 
344 cancer cells (Koike et al., 2006) and that both $\mathrm{p} 21^{\mathrm{waf} 1 / \mathrm{cip} 1}$ and $\mathrm{p} 27^{\mathrm{kip} 1}$ play an important role in

345 attenuating thyroid cancer growth (Podtcheko et al., 2003; Yang et al., 2003).

346 We were able to observe a decreased phosphorylation of the Rb-protein at Ser-780 and 347 especially Ser-795 in PMA treated cells. This is an important observation, as the Rb-protein is 348 a central nuclear protein in regulating the progression of cells through the G1-S phase of the 349 cell cycle (Massague, 2004). We assume that this hypophosphorylation of $\mathrm{Rb}$ was the result 350 of the decrease in both cyclin D3 and cdk4/6. In SKBR-3 breast cancer cells, the PMA evoked 351 inhibition of proliferation was mediated by a PKC $\delta$-evoked hypophosphorylation of the $\mathrm{Rb}$ 352 protein, although the mechanism was not eluded (Yokoyama et al., 2005).

353 Previous studies have shown that a transient MAP kinase activation is linked to cell 354 cycle progression, whereas sustained levels of MAP kinase activity can lead to cell growth 355 arrest (Clark et al., 2004). Furthermore, the MAP kinase pathway is essential for G1- to S356 phase progression and is associated with induction of positive regulators of the cell cycle 357 (Meloche and Pouyssegur, 2007). Our results show that acute stimulation of the cells with 358 PMA resulted in an increase of the phosphorylation levels of MAP kinase, while prolonged 359 stimulation decreased the phosphorylation of this kinase. Similar results were recently also 360 observed in FRO cells stimulated with sphingosylphosphorylcholin, a bioactive lipid that 361 potently abrogated both migration and proliferation of FRO cells, although in these 362 experiments the cells were arrested in the G2/M phase of the cell cycle (Afrasiabi et al., 363 2007). As MAP kinase is an important regulator of proliferation in several cells, including 364 thyroid cells, this decrease probably also is of importance in the PMA-evoked inhibition of 365 proliferation. Interestingly, although PMA evoked an acute stimuation of MAP kinase 366 phosphorylation, we were able to observe an inhibition of ${ }^{3} \mathrm{H}$-thymidine incorporationa 367 already after $2 \mathrm{~h}$ of incubation with PMA. The results suggest that the onset of inhibition is 
368

369

370

371

372

373

374

375

376

377

378

379

380

381

382 Acknowledgements

383 The authors are grateful to Mr. Esa Nummelin for technical assistance. This study was

384 supported in part by the K. Albin Johansson Foundation, the Magnus Ehrnrooth foundation,

385 Stiftelsens för Åbo Akademi forsningsinstitut, the Liv och Hälsa Foundation, the Centre of 386

387

388

389

390

391

initiated very rapidly after stimulation. Possibly some PKC isoform other than PKC $\delta$ is mediating the early phosphorylation of MAP kinase.

We have not further investigated the mechanism by which PMA inhibited migration, as the low level of siRNA transfection precluded a more thorough investigation. However, it is tempting to speculate that $\mathrm{PKC} \delta$ also is regulating migration in FRO cells. This isoform has been shown to be responsible for the inhibition of migration of prostate cancer cells, smooth muscle cells, and Madin Darby canine kidney cells (Kharait et al., 2006; Liu et al., 2007; Chen et al., 2007).

proliferation and migration of human thyroid FRO anaplastic cancer cells. At least the inhibition of proliferation seems to be mediated by $\mathrm{PKC} \delta$. Our results suggest that targeted activation of PKC $\delta$ could be an effective means to evoke substantial inhibition of thyroid cancer cell proliferation. Excellence in Cell Stress (Åbo Akademi University) and the Receptor Research Program (Åbo Akademi University and the University of Turku), which are gratefully acknowledged. We are also indebted to Dr. Marcelo Kazanietz for helpful suggestions.

\section{References}

Afrasiabi E., Blom T., Ekokoski E., Tuominen R.K., Tornquist K., 2006. Sphingosyl- 
392

393

394

395

396

397

398

399

400

401

402

403

404

405

406

407

408

409

410

411

412

413

414

416 415 treatment by anticancer agents. Cell Cycle, 3, 46-50.

phosphorylcholine enhances calcium entry in thyroid FRO cells by a mechanism dependent on protein kinase C. Cell. signal. 18, 1671-1678.

Afrasiabi E., Blom T., Balthasar S., Törnquist K., 2007. Antiproliferative effect of sphingosylphosphorylcholine in thyroid FRO cancer cells mediated by cell cycle arrest in the G2/M phase. Mol. Cell. Endocrinol. 274, 43-52.

Arden K.C., 2006. Multiple roles of FOXO transcription factors in mammalian cells point to multiple roles in cancer. Exp. Gerontol., 141, 709-717.

Blumberg P.M., Delclos K.B., Dunn J.A., Jaken S., Leach K.L., Yeh E., 1983. Phorbol ester receptors and the in vitro effects of tumor promoters. Ann. NY. Acad. Sci., 407, $303-$ 315.

Brunet A., Bonni A., Zigmond M.J., Lin M.Z., Juo P., Hu L.S., Anderson M.J., Arden K.C., Blenis J., Greenberg M.E., 1999. Akt Promotes Cell Survival by Phosphorylating and Inhibiting a Forkhead Transcription Factor. Cell, 96, 857-868.

Clark J.A., Black A.R., Leontieva O.V., Frey M.R., Pysz M.A., Kunneva L., WoloszynskaRead A., Roy D., Black J.D., 2004. Involvement of the ERK signaling cascade in protein kinase C-mediated cell cycle arrest in intestinal epithelial cells. J. Biol. Chem., $279,9233-9247$.

Cerda S.R., Mustafi R., Little H., Cohen G., Khare S., Moore C., Majumder P., Bissonnette M., 2006. Protein kinase C delta inhibits Caco-2 cell proliferation by selective changes in cell cycle and cell death regulators. Oncogene, 25, 3123-3138.

Chen C.L., Hsieh Y.T., Chen H.C., 2007. Phosphorylation of adducin by protein kinase Cdelta promotes cell motility. J. Cell Sci., 120, 1157-1167.

Damia G., Broggini M., 2004. Cell cycle checkpoint proteins and cellular response to

Dehan E., Pagano M., 2005. Skp2, the FoxO1 hunter. Cancer Cell, 7, 209-210. 
417 Dyson N., 1998. The regulation of E2F by pRB-family proteins. Genes Dev., 12, 2245-2262.

418 Frey M,R., Clark J.A., Leontieva O., Uronis J.M., Black A.R., Black J.D., 2000. Protein

419 kinase C signaling mediates a program of cell cycle withdrawal in the intestinal $420 \quad$ epithelium. J. Cell Biol., 151, 763-778.

421 Gauthier M.L., Torretto C., Ly J., Francescutti V., O’Day D.H., 2003. Protein kinase Calpha 422 negatively regulates cell spreading and motility in MDA-MB-231 human breast cancer cells downstream of epidermal growth factor receptor. Biochem. Biophys. Res.

425

426

427

428

429

430

431

432

433

434

435

436

437

438

439

440

441 Commun., 307, 839-846.

Griner E.M., Kazanietz M.G., 2007. Protein kinase C and other diacylglycerol effectors in cancer. Nat. Rev. Cancer., 7, 281-294.

Kass G.E.N., Duddy S.K., Orrenius S., 1989. Activation of hepatocyte protein kinase C by redox-cycling quinines. Biochem. J., 260, 499-507.

Kharait S., Dhir R., Lauffenburger D., Wells A., 2006. Protein kinase Cdelta signaling downstream of the EGF receptor mediates migration and invasiveness of prostate cancer cells. Biochem. Biophys. Res. Commun., 343, 848-856.

Koike K., Fujii T., Nakamura A.M., Yokoyama G., Yamana H., Kuwano M., Shirouzu K., 2006. Activation of protein kinase C delta induces growth arrest in NPA thyroid cancer cells through extracellular signal-regulated kinase mitogen-activated protein kinase. Thyroid, 16, 333-341.

Kraiem Z., Sadeh O., Yosef M., Aharon A., 1995. Mutual antagonistic interactions between the thyrotropin (adenosine 3',5'-monophosphate) and protein kinase C/epidermal growth factor (tyrosine kinase) pathways in cell proliferation and differentiation of cultured human thyroid follicles. Endocrinology, 136, 585-90.

Levesque J.T., Siard M.A., 1995. Effects of different kinases and phosphatases on nuclear and cytoplasmic maturation of bovine oocytes. Mol. Reprod. Dev., 42, 114-121. 
442 Liang J., Slingerland J.M., 2003. Multiple roles of the PI3K/PKB (Akt) pathway in cell cycle 443 progression. Cell Cycle, 2, 339-345.

444 Liu B., Ryer E.J., Kundi R., Kamiya K., Itoh H., Faries P.L., Sakakibara K., Kent K.C., 2007. 445 Protein kinase C-delta regulates migration and proliferation of vascular smooth muscle 446 cells through the extracellular signal-regulated kinase 1/2. J. Vasc. Surg., 45, 160-168.

447 Lombardi A., Veneziani B.M., Tramontano D., Ingbar S.H., 1988. Independent and 448 interactive effects of tetradecanoyl phorbol acetate on growth and differentiated 449 functions of FRTL5 cells. Endocrinology, 123, 1544-1552.

450 Martin P.M., Aeder S.E., Chrestensen C.A., Sturgill T.W., Hussaini I.M., 2007. Phorbol $12-$ 451 myristate 13-acetate and serum synergize to promote rapamycin-insensitive cell 452 proliferation via protein kinase C-eta. Oncogene, 26, 407-414.

453 Massague J., 2004. G1 cell-cycle control and cancer. Nature, 432, 298-306.

454 Medema R.H., Kops G.J., Bos J.L., Burgering B.M., 2000. AFX-like Forkhead transcription 455 factors mediate cell-cycle regulation by Ras and PKB through p27kip1. Nature, 404, $456 \quad 782-787$.

457 Meloche S., Pouyssegur J., 2007. The ERK 1/2 mitogen-activated protein kinase pathway as a 458 master regulator of the G1- to S-phase transition. Oncogene, 26, 3227-3239.

459 Myatt S.S., Lam E.W., 2007. The emerging roles of forkhead box (Fox) proteins in cancer. $460 \quad$ Nat. Rev. Cancer, 7, 847-859.

461 Nakagawa M., Oliva J.L., Kothapalli D., Fournier A., Assoian R.K., Kazanietz M.G., 2005. 462 Phorbol ester-induced $\mathrm{G}_{1}$ phase arrest selectively mediated by protein kinase $\mathrm{C} \delta$ 463 dependent induction of p21. J. Biol. Chem., 280, 33926-33934.

464 Newton A.C., 2001. Protein kinase C: structural and spatial regulation by phosphorylation, 465 cofactors, and macromolecular interactions. Chem. Rev., 101, 2353-2364. 
466 Nevins J.R., 1998. Toward an understanding of the functional complexity of the E2F and 467 retinoblastoma families. Cell Growth Differ., 9, 585-593.

468 Nishizuka Y., 1986. Studies and prespectives of protein kinase C. Science, 233, 305-312.

469 Nishizuka Y., 1988. The molecular heterogeneity of protein kinase C and its implications for $470 \quad$ cellular regulation. Nature, 334, 661-665.

471 Perletti G., Marras E., Dondi D., Osti D., Congiu T., Ferrarese R., de Eguileor M., Tashjian 472 A.H, Jr, 2005. p21(Wafl/Cip1) and p53 are downstream effectors of protein kinase C 473 delta in tumor suppression and differentiation in human colon cancer cells. Int. J. $474 \quad$ Cancer., 113, 42-53.

475 Pettersson F., Couture M.C., Hanna N., Miller W.H., 2004. Enhanced retinoid-induced 476 apoptosis of MDA-MB-231 breast cancer cells by PKC inhibitors involves activation of ERK. Oncogene, 23, 7053-7066.

Podtcheko A., Ohtsuru A., Tsuda S., Namba H., Saenko V., Nakashima M., Mitsutake N., Kanda S., Kurebayashi J., Yamashita S., 2003. The selective tyrosine kinase inhibitor, 482 Roger P.P., Reuse S., Servais P., Van Heuverswyn B., Dumont J.E., 1986. Stimulation of cell 483 proliferation and inhibition of differentiation expression by tumor-promoting phorbol esters in dog thyroid cells in primary culture. Cancer Res., 46, 898-906.

Sinibaldi D., Wharton W., Turkson J., Bowman T., Pledger W.J., Jove R., 2000. Induction of p21WAF1/CIP1 and cyclin D1 expression by the Src oncoprotein in mouse fibroblasts: role of activated STAT3 signaling. Oncogene, 19, 5419-5427.

Shinohara M., Chung Y.J., Saji M., Ringel M.D., 2007. Minireview: Akt in thyroid 489 tumorigenesis and progression. Endocrinology, 148, 942-947. 
491

492

493

494

495

496

497

498

499

500

501

502

503

504

505

506

507

508

509

melanoma cells is regulated by adhesion-dependent phosphatidylinositol 3-kinase signaling and contributes to G1-S progression. J. Biol. Chem., 281, 25644-51.

Takada K., Amino N., Tetsumoto T., Miyai K., 1988. Phorbol esters have adual action through protein kinase $\mathrm{C}$ in regulation of proliferation on FRTL-5 cells. FEBS Lett., 234, 13-16.

Yang H.L., Pan J.X., Sun L., Yeung S.C., 2003. p21 Waf-1 (Cip-1) enhances apoptosis induced by manumycin and paclitaxel in apoptosis induced by manumycin and paclitaxel in anaplasticthyroid cancer cells. J. Clin. Endocrinol. Metab., 88, 763-772.

Yokoyama G., Fujii T., Tayama K., Yamana H., Kuwano M., Shirouzu K., 2005. PKCd and MAPK mediate G1 arrest induced by PMA in SKBR-3 breast cancer cells. Biochem. Biophys. Res. Commun., 327, 720-726.

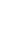


510 Table 1. Effects of PMA, 4 $\alpha$-phorbol and DOG on the cell cycle of FRO cells.

511

\begin{tabular}{|l|l|l|l|l|}
\hline Cell cycle phase & C & PMA & $4 \alpha$-phorbol & DOG \\
\hline G0-G1 & $62.8 \pm 1.6$ & $75.3 \pm 1.3^{* *}$ & $62.9 \pm 0.5$ & $63.6 \pm 0.9$ \\
\hline $\mathrm{S}$ & $19.1 \pm 0.5$ & $11.9 \pm 0.7^{* *}$ & $19.3 \pm 0.2$ & $19.1 \pm 0.4$ \\
\hline $\mathrm{G}_{2}-\mathrm{M}$ & $9.1 \pm 0.6$ & $6.2 \pm 0.4^{* *}$ & $9.3 \pm 0.3$ & $8.9 \pm 0.3$ \\
\hline
\end{tabular}

512 Cells were treated either with vehicle (C), 100 nM PMA, $1 \mu \mathrm{M} 4 \alpha$-phorbol or $10 \mu \mathrm{M}$ DOG.

513 After $24 \mathrm{~h}$ the cells were collected and analyzed for the distribution of cells in the cell cycle

514 using FACS analysis. The data gives the mean \pm SEM of three separate experiments. **, $\mathrm{P}<$

5150.01 compared with respective control value. 
516 Table 2. Effect of PMA on the expression levels of the cell cycle regulatory proteins.

\begin{tabular}{|l|l|l|}
\hline Protein & C & PMA \\
\hline cyclin D1 & $1.00 \pm 0.07$ & $0.97 \pm 0.06$ \\
\hline cyclin D2 & $1.03 \pm 0.06$ & $1.09 \pm 0.06$ \\
\hline cyclin D3 & $1.00 \pm 0.07$ & $0.57 \pm 0.03^{*}$ \\
\hline cyclin E & $1.12 \pm 0.17$ & $0.94 \pm 0.13$ \\
\hline cdk2 & $1.03 \pm 0.03$ & $0.98 \pm 0.05$ \\
\hline cdk4 & $1.18 \pm 0.07$ & $0.82 \pm 0.05^{*}$ \\
\hline cdk6 & $1.15 \pm 0.05$ & $0.71 \pm 0.06^{*}$ \\
\hline p21 & $0.68 \pm 0.15$ & $1.32 \pm 0.17^{*}$ \\
\hline p27 & $0.77 \pm 0.08$ & $1.3 \pm 0.12^{*}$ \\
\hline pRb (Ser780) & $1.16 \pm 0.01$ & $0.84 \pm 0.03^{*}$ \\
\hline pRb (Ser795) & $1.33 \pm 0.18$ & $0.66 \pm 0.13^{*}$ \\
\hline
\end{tabular}

518 FRO cells were treated with vehicle (C), or with $100 \mathrm{nM}$ PMA for $24 \mathrm{~h}$ and western blot

519 analysis were performed. Densitometric results were corrected by normalization for $\beta$-actin expression except with $\mathrm{pRb}($ Ser780) and pRb (Ser795) which were normalized against the

521 total $\mathrm{Rb}$. Values given are the mean \pm SEM of three independent experiments. $*, \mathrm{P}<0.05$

522 compared with respective control value. 
523 Table 3. Effect of PMA on the expression levels of p21 and p27 in cells transfected with

$524 \mathrm{PKC} \alpha(\operatorname{si\alpha })$ or $\mathrm{PKC} \delta(\operatorname{si} \delta)$ siRNA.

\begin{tabular}{|l|l|l|l|l|l|l|}
\hline Protein & C & PMA & si $\alpha$ & si $\alpha+$ PMA & si $\delta$ & si $\delta+P M A$ \\
\hline p21 & $1 \pm 0.04$ & $1.7 \pm 0.1^{*}$ & $1.0 \pm 0.06$ & $1.74 \pm 0.03^{* *}$ & $1.03 \pm 0.02$ & $1.0 \pm 0.04$ \\
\hline p27 & $1 \pm 0.0 .25$ & $1.78 \pm 0.07^{*}$ & $0.93 \pm 0.07$ & $1.56 \pm 0.08^{*}$ & $1.04 \pm 0.1$ & $1.03 \pm 0.03$ \\
\hline
\end{tabular}

525

526 Control cells (C), cells transfected with PKC $\alpha(\operatorname{si\alpha })$ or PKC $\delta$ (si $\delta)$ siRNA were treated with

527 vehicle or with $100 \mathrm{nM}$ PMA and cellular proteins were extracted after $24 \mathrm{~h}$. Western blott

528 analysis were performed using antibodies against $\mathrm{p} 27^{\mathrm{kip} 1}$ and $\mathrm{p} 21^{\mathrm{wafl} / \mathrm{cip} 1}$. Densitometric results

529 were corrected by normalization for $\beta$-actin Values given are the mean \pm SEM of three

530 independent experiments. * $\mathrm{P}<0.05, * *, \mathrm{P}<0.01$ compared to the respective control value. 


\section{$531 \quad$ Legands to the figures}

532 Figure 1: Antiproliferative effects of PMA in FRO, ARO and ML-1 thyroid cancer cells. A.

533 FRO and ARO cells were grown in 35-mm dishes under conditions of low (5\% lipid-stripped)

534 serum and after treatment with vehicle (0) or with different concentrations of PMA, $1 \mu \mathrm{M} 4 \alpha$ -

535 phorbol $(\alpha-\mathrm{ph})$ or $10 \mu \mathrm{M}$ DOG for $24 \mathrm{~h},{ }^{3} \mathrm{H}$-thymidine incorporation assay was performed as

536 described in the methods section. B. FRO cells were treated with $100 \mathrm{nM}$ PMA and the ${ }^{3} \mathrm{H}-$

537 thymidine incorporation assay was performed after 2, 4 and 8 h. C. In the Celltiter assay,

538 FRO and ML-1 cells were grown on 96-wells plates and treated with vehicle (0) or with

539 different doses of PMA, $1 \mu \mathrm{M} 4 \alpha$-phorbol or $10 \mu \mathrm{M}$ DOG for $24 \mathrm{~h}$ and the absorbance at 540

$540 \mathrm{~nm}$ was measured as described in the methods section. D. PMA reduces FRO cell number.

541 Cell counting was performed after a 24 h-stimulation with either vehicle (C), 100 nM PMA, 1

$542 \mu \mathrm{M} 4 \alpha$-phorbol $(\alpha-\mathrm{ph}) \quad$ or $10 \mu \mathrm{M}$ DOG. Data are expressed as percent proliferated cells

543 compared to untreated controls. The bars give the mean \pm SEM of 4-6 experiments $(*, \mathrm{P}<$

$5440.05, * *, \mathrm{P}<0.01, * * *, \mathrm{P}<0.001)$. E. FRO cells were treated with vehicle or with $100 \mathrm{nM}$ of

545 PMA, and after $24 \mathrm{~h}$, cells were washed twice with PBS, counted and then replated and the

$546{ }^{3} \mathrm{H}$-thymidine incorporation assay was performed after $24 \mathrm{~h}, 48 \mathrm{~h}$ and $96 \mathrm{~h}$ respectively, as

547 described in the methods section. Data are expressed as percent proliferated cells compared to

548 untreated controls. The bars give the mean \pm SEM of $4-6$ experiments $(*, \mathrm{P}<0.05)$. F. Effects

549 of PMA on FRO cell morphology. FRO cells were grown as for the proliferation experiment

550 in $35 \mathrm{~mm}$ culture dishes and treated with vehicle (C) or $100 \mathrm{nM}$ PMA (PMA). The cells were

551 monitored microscopically prior to $(0 \mathrm{~min})$ and after $3 \mathrm{~min}, 5 \mathrm{~min}, 15 \mathrm{~min}$ and $30 \mathrm{~min}$ of

552 stimulation, and images were recorded with a CCD camera. Each experiment was performed $553 \quad 3-6$ times.

554 
555 Figure 2: Antimigratory effect of PMA on FRO, ARO and ML-1 thyroid cancer cell

556 migration. A. FRO cells were grown on Transwell inserts coated with collagen I as described

557 in the methods section, and after treatment with vehicle (0), $10 \mathrm{nM}$ or $100 \mathrm{nM}$ PMA, $1 \mu \mathrm{M}$

$5584 \alpha$-phorbol, or $10 \mu \mathrm{M} \mathrm{DOG}$, cells that had migrated towards lipid-stripped FBS were counted.

559 ML-1 and ARO cells were grown on Transwell inserts coated with collagen I, and after

560 treatment with vehicle (0), or the indicated concentration of PMA, cells that had migrated

561 towards lipid-stripped FBS were counted. Each experiment was performed 3-6 times. Data are

562 expressed as percent migrated cells compared to untreated controls $(*, \mathrm{P}<0.05, * *, \mathrm{P}<0.01)$.

563 B. Representative microscopic images of the Transwell inserts of FRO cells treated with

564 vehicle (C), or with $100 \mathrm{nM}$ PMA. The arrow indicates some migrated cells after PMA 565 treatment.

566

567 Figure 3: PMA evokes cell cycle changes. A. FRO cells were grown on 35-mm plates and 568 treated with vehicle (C), or with $100 \mathrm{nM}$ PMA for $24 \mathrm{~h}$, and then incubated with propidium 569 iodide and analysed by FACS for cell cycle measurements as described in the methods 570 section. Axes were scaled differently to show sub-G1 population of cells. Each experiment was performed 4-6 times. B. Effects of PMA on the levels and activity of cell cycle regulatory

572 proteins in FRO thyroid cancer cells. Cells were treated with vehicle (C) or 100 nM PMA, 573 and cellular proteins were extracted after $24 \mathrm{~h}$. A total of $15 \mu \mathrm{g}$ cell extract protein isolated 574 from the treated and the untreated cells was subjected to SDS-PAGE and immunoblotted with 575 antibodies against cyclin D1, cyclin D2, cyclin D3, cyclin E, cdk2, cdk4, cdk6, p21 ${ }^{\text {waf1/cip1, }}$ $576 \mathrm{p} 27^{\text {kip1 }}$, phospho-Rb (Ser780), phospho-Rb (Ser795) and total Rb. Filters were reblotted with

577 an anti- $\beta$-actin antibody to normalize for protein loading. Western blot data presented are 578 representative of 3 separate experiments. 
580

581

582

583

584

585

586

587

588

589

590

591

592

593

594

595

596

597

598

599

600

601

602

603 Figure 6: Effects of PMA on the phosphorylation levels of MAP kinase, Akt and FOXO in 604

Figure 4: Translocation of different PKC isoforms after stimulation with PMA. The cells were stimulated with $100 \mathrm{nM}$ PMA and fractionated as described in the methods section. The blots show the effect of PMA on the distribution of $\mathrm{PKC} \alpha, \mathrm{PKC} \beta \mathrm{I}, \mathrm{PKC} \delta$ and $\mathrm{PKC} \zeta$ between the cytosolic and the particulate fractions before $(0 \mathrm{~min})$ and after $1 \mathrm{~min}, 5 \mathrm{~min}$ and 10 min stimulation. Each experiment was performed 3 times.

Figure 5: The inhibitory effect of PMA on proliferation is mediated by $\mathrm{PKC} \delta$. A. Cells were grown on $35 \mathrm{~mm}$ culture dishes for $24 \mathrm{~h}$ and subsequently transfected with a negative control dsRNAs (C-), or with PKC $\alpha$ and PKC $\delta$ dsRNAs (Si). After 24 h proteins were extracted from the transfected and nontransfected cells (C) and western blots were carried out using antibodies against $\mathrm{PKC} \alpha$ and $\mathrm{PKC} \delta$. Filters were reblotted with an anti- $\beta$-actin antibody to normalize for protein loading. B. Summary of the densitometric analysis of the transfection experiments. Western blot data presented are representative of three separate experiments. (*, $\mathrm{P}<0.05, * *, \mathrm{P}<0.01)$. C. Negative control dsRNAs cells $(\mathrm{C})$, or cells transfected with specific dsRNAs for either PKC $\alpha(\alpha)$ and $\operatorname{PKC} \delta(\delta)$ were treated with 100 nM PMA and the ${ }^{3} \mathrm{H}$-thymidine incorporation assay was performed after $24 \mathrm{~h}$ as described in the methods section. Data are expressed as percent proliferated cells compared to untreated controls. The bars give the mean \pm SEM of 4-6 experiments (***, $\mathrm{P}<0.001$ compared with control cells).

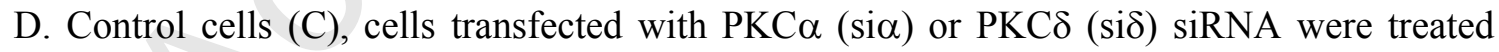
with vehicle (-) or $100 \mathrm{nM}$ PMA (+) and cellular proteins were extracted after $24 \mathrm{~h}$. Western blott analysis were performed using antibodies against $\mathrm{p} 27^{\mathrm{kip} 1}$ and $\mathrm{p} 21^{\text {wafl/cip1 }}$. Anti- $\beta$-actin antibody was used to normalize for protein loading. Each experiment was performed 3 times.

FRO thyroid cancer cells. A. Cells were treated with vehicle (0), or $100 \mathrm{nM}$ PMA in medium 
605 containing 5\% lipid-stripped FBS and cellular proteins were extracted after 5, 15, 30, and 60

606 min. B. Cells were treated with vehicle (0), or 100 nM PMA in medium containing 5\% lipid-

607 stripped FBS and cellular proteins were extracted after $24 \mathrm{~h}$. A total of $15 \mu \mathrm{g}$ cell extract

608 protein isolated from the treated and the untreated cells was subjected to SDS-PAGE and

609 immunoblotted with antibodies against phospho-p44/42 MAP kinase (Thr-202/Tyr-204), and

610 p44/42 MAP kinase. C. Cells were treated with vehicle (C), or $100 \mathrm{nM}$ PMA for 30 min and

611 antibodies against phospho-Akt (Thr-308) and Akt were used. D. Cells were treated with

612 vehicle (C), or $100 \mathrm{nM}$ PMA for $30 \mathrm{~min}$ and antibodies against phospho-FOXO1 (Ser-256)

613 and FOXO1 were used as described previously. E. Cells were treated with vehicle (C), or 100

614 nM PMA for $24 \mathrm{~h}$ and antibodies against phospho-FOXO1 (Ser-256) and FOXO1 were used.

615 Densitometric analysis was performed and data was normalised against cells treated with

616 vehicle $(*, \mathrm{P}<0.05, * *, \mathrm{P}<0.01, * * *, \mathrm{P}<0.001)$. Western blot data presented are

617 representative of 3 separate experiments. 
A
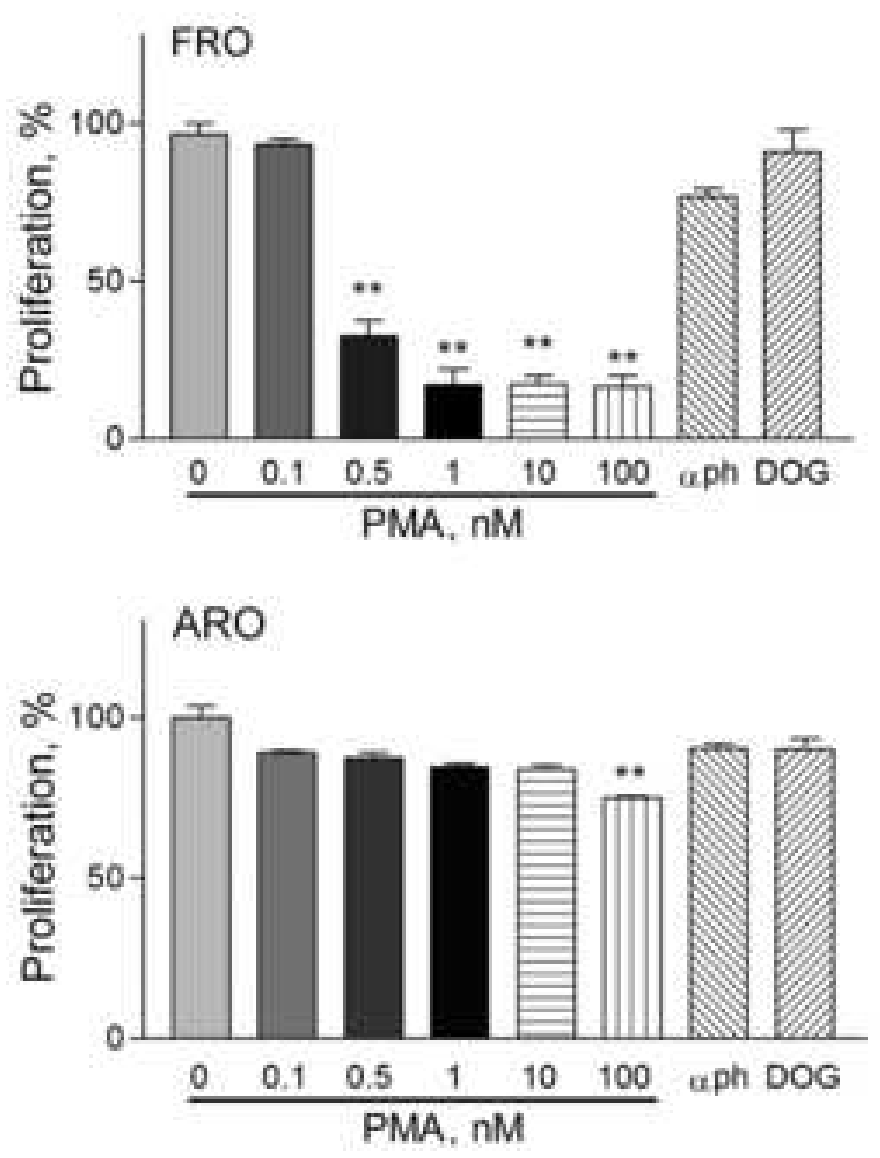

C
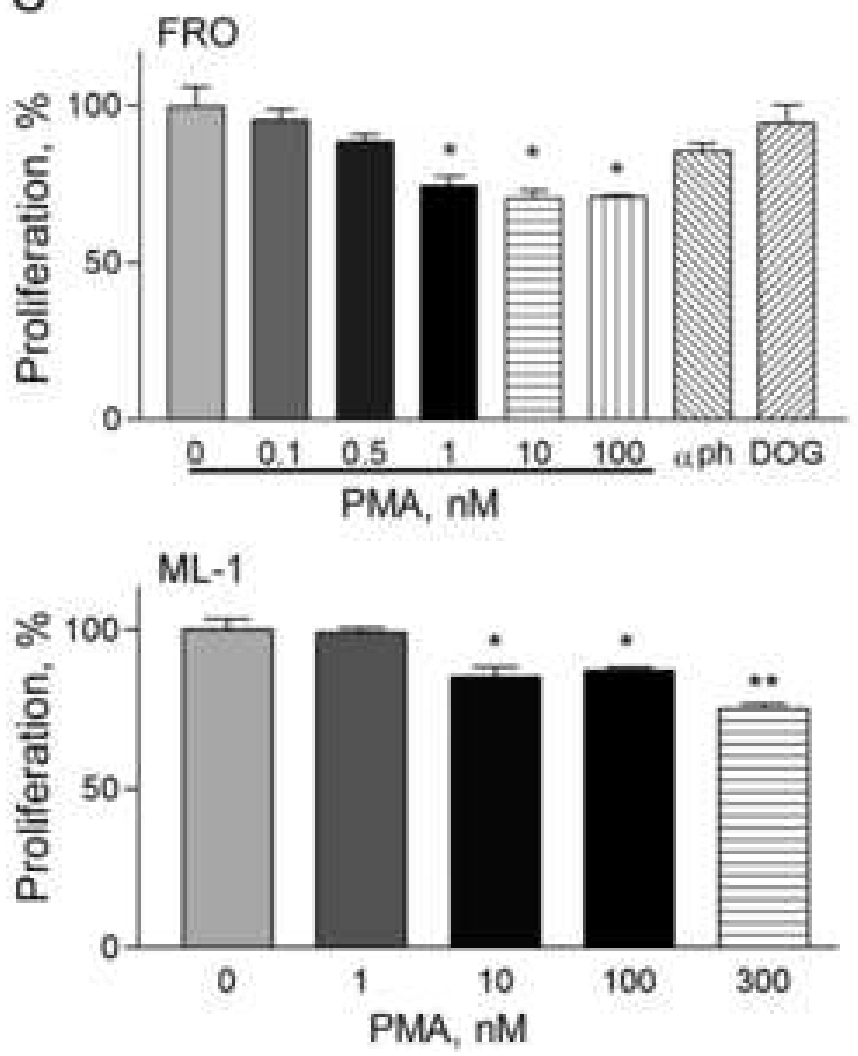

B
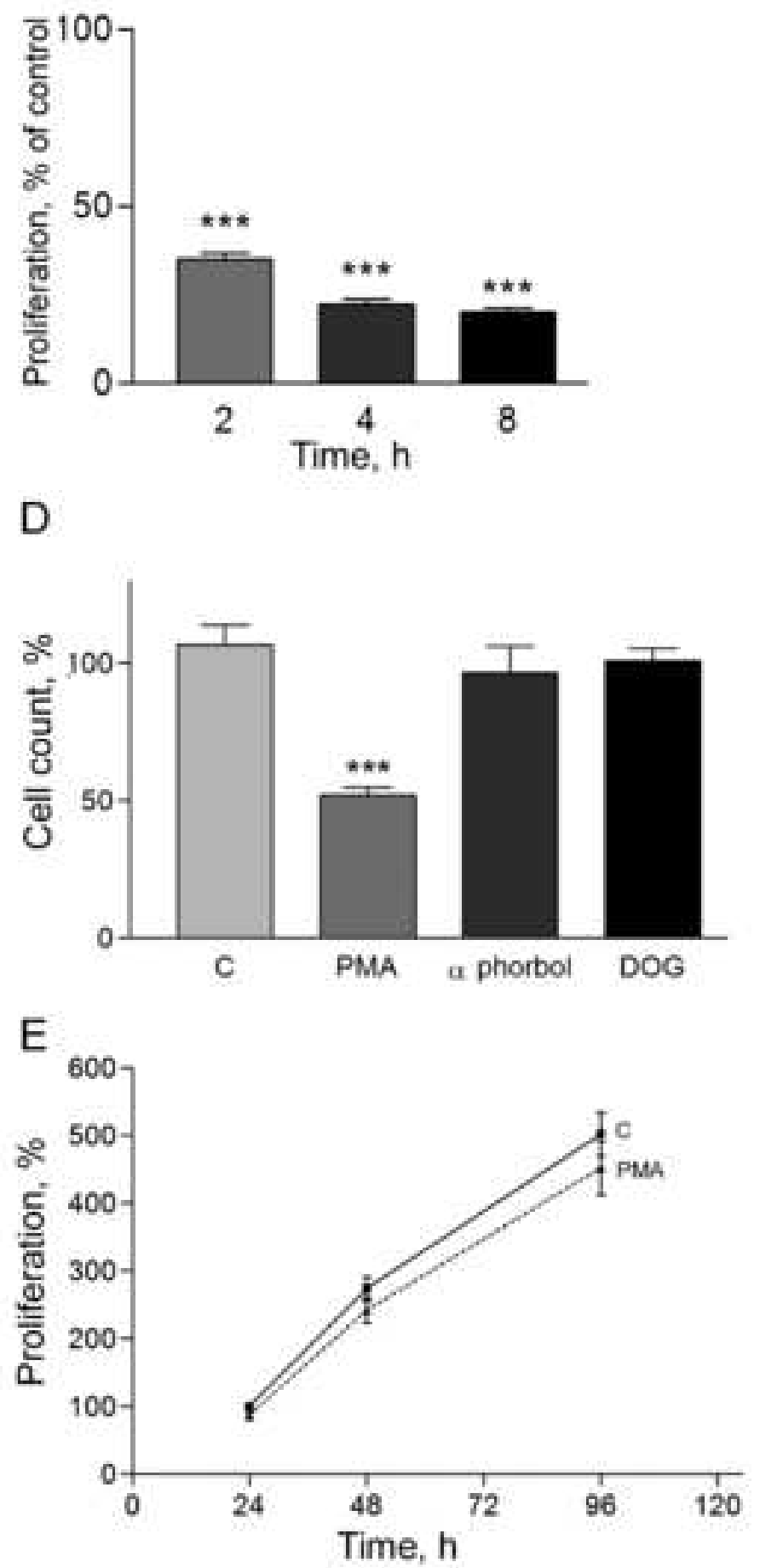

F
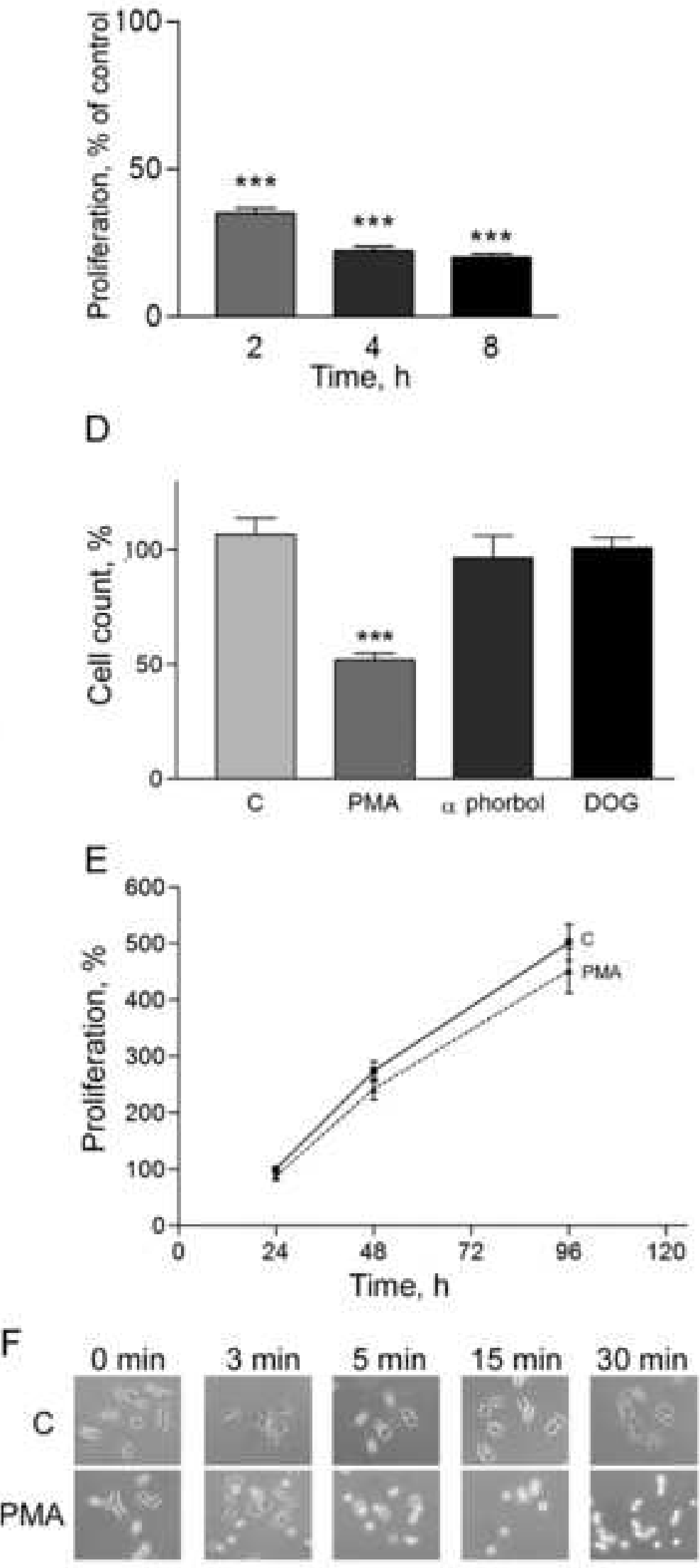


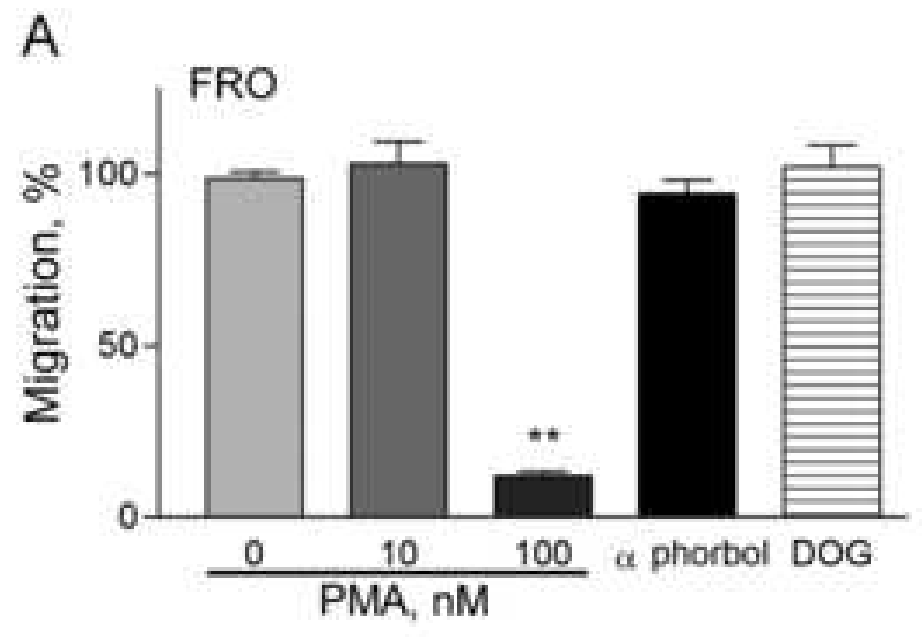

B

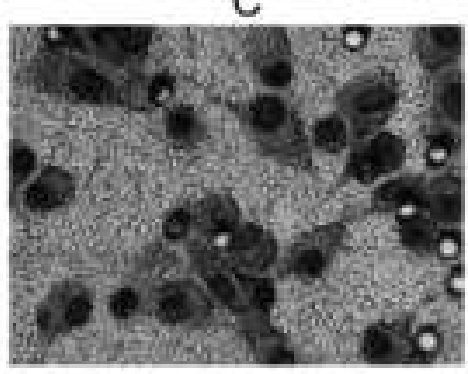

PMA

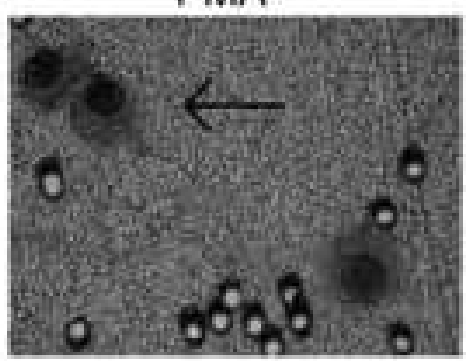

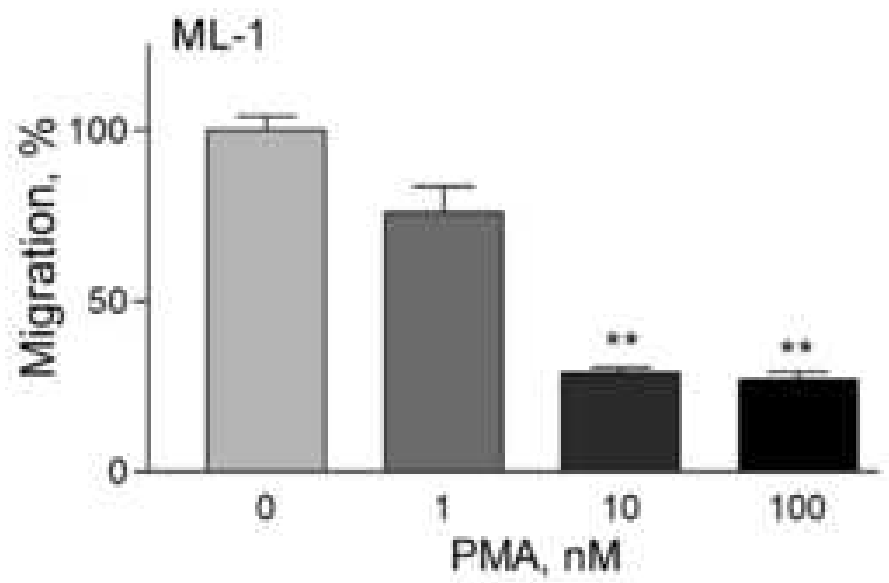

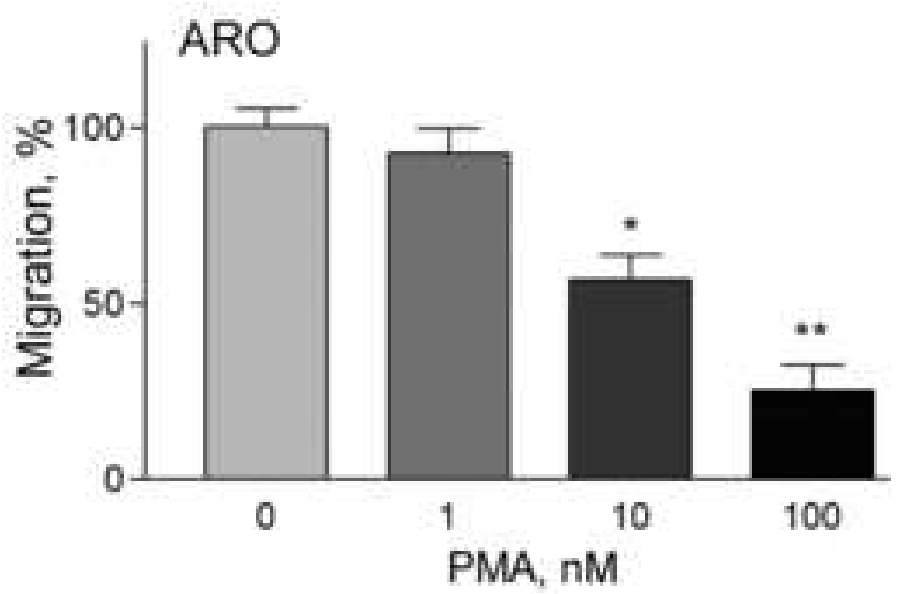


A
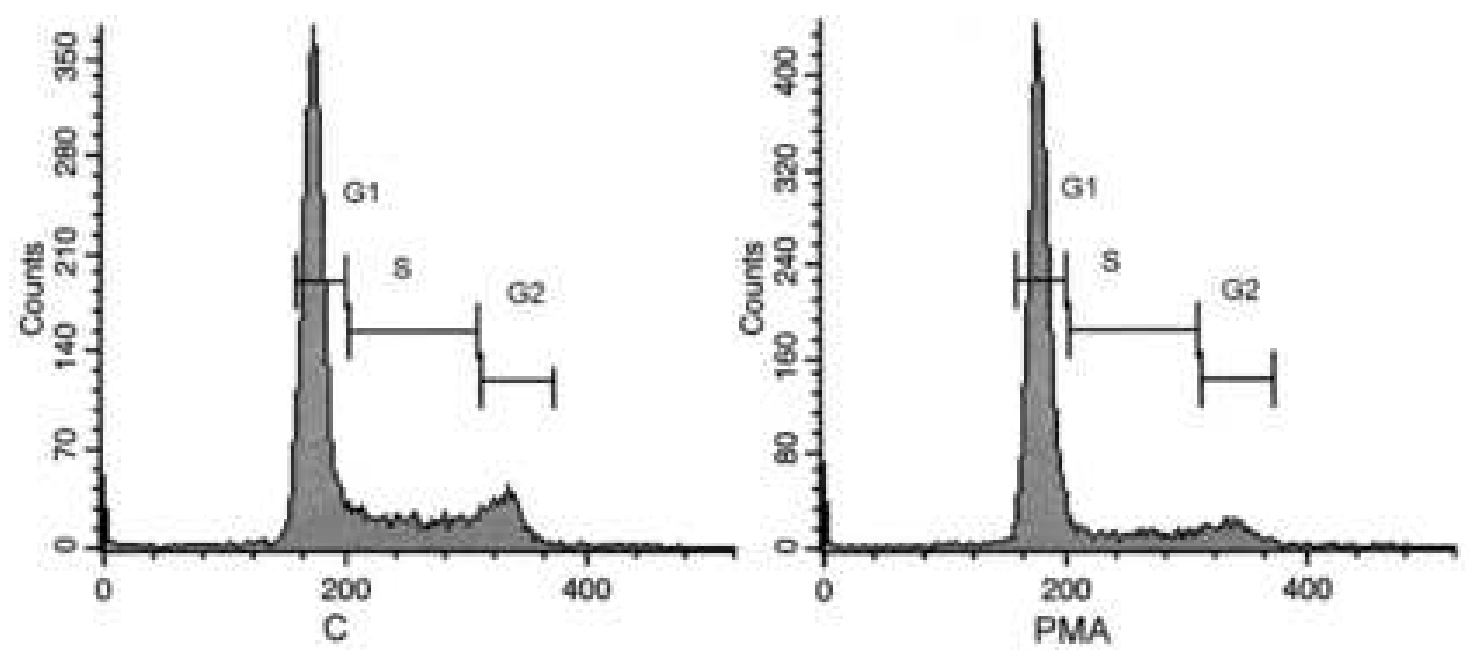

B

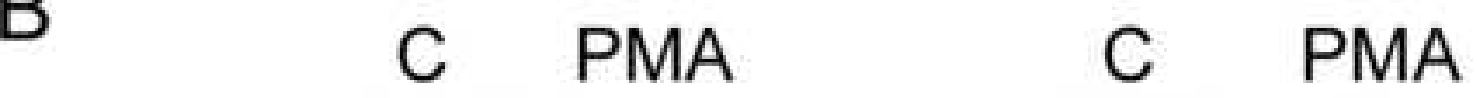

cyclin D1

cyclin D2

cyclin D3

cyclin E

ß-actin cdk2

cdk4

cdk6

p21

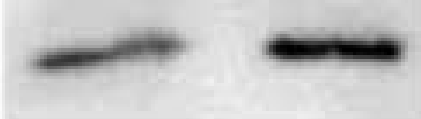

3-actin

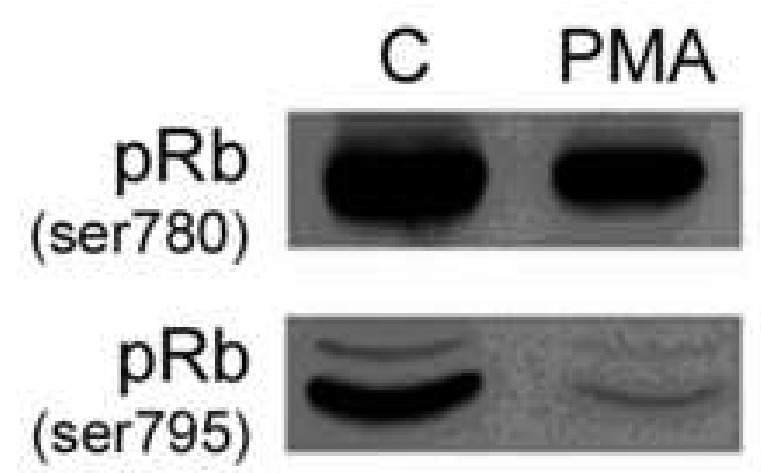

$\mathrm{Rb}$

p27

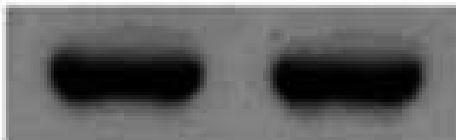

sincisto

ß-actin 


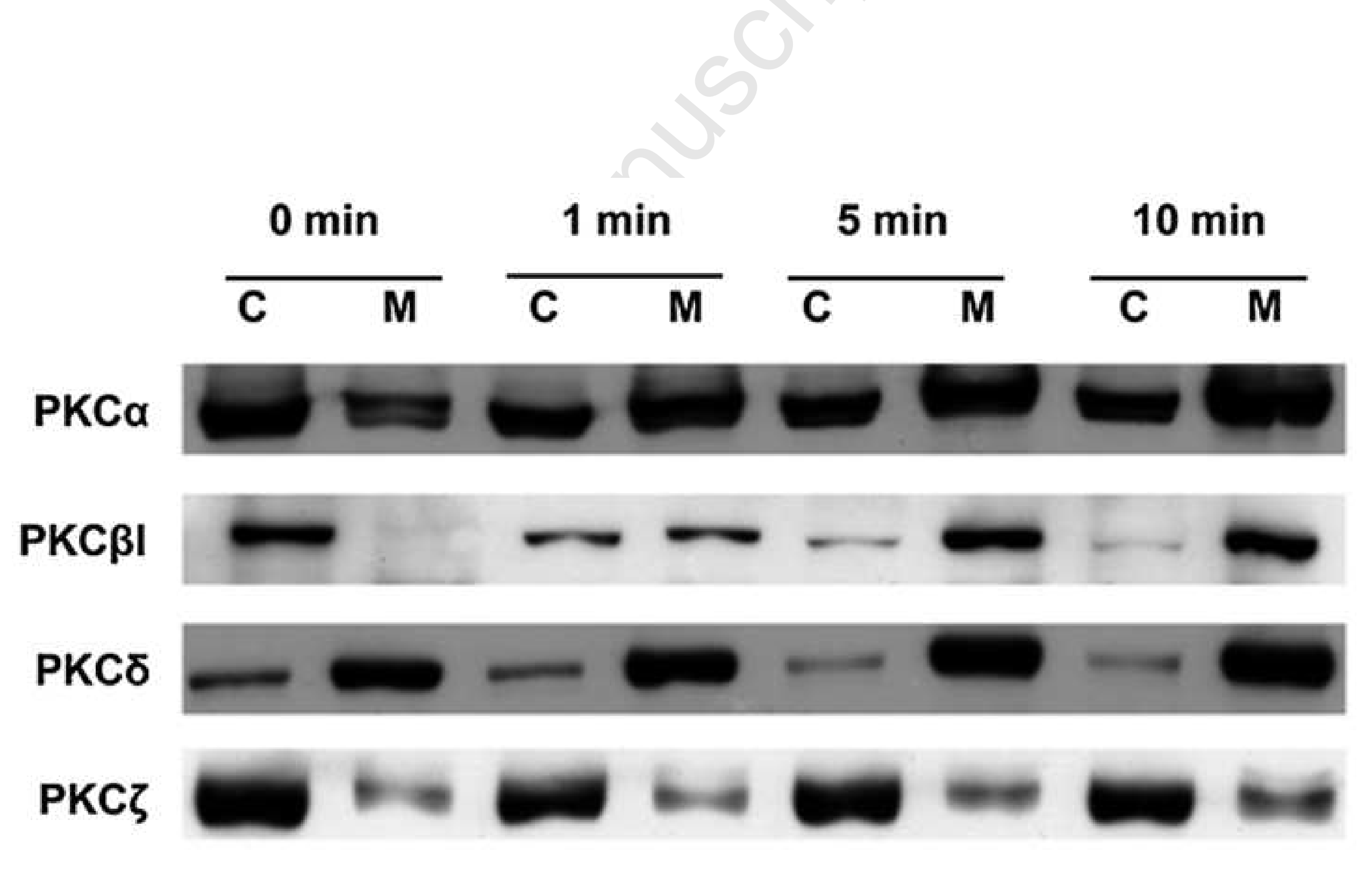

PKC $\beta I$

(a)

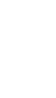

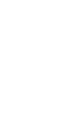

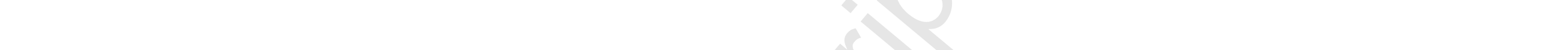

(
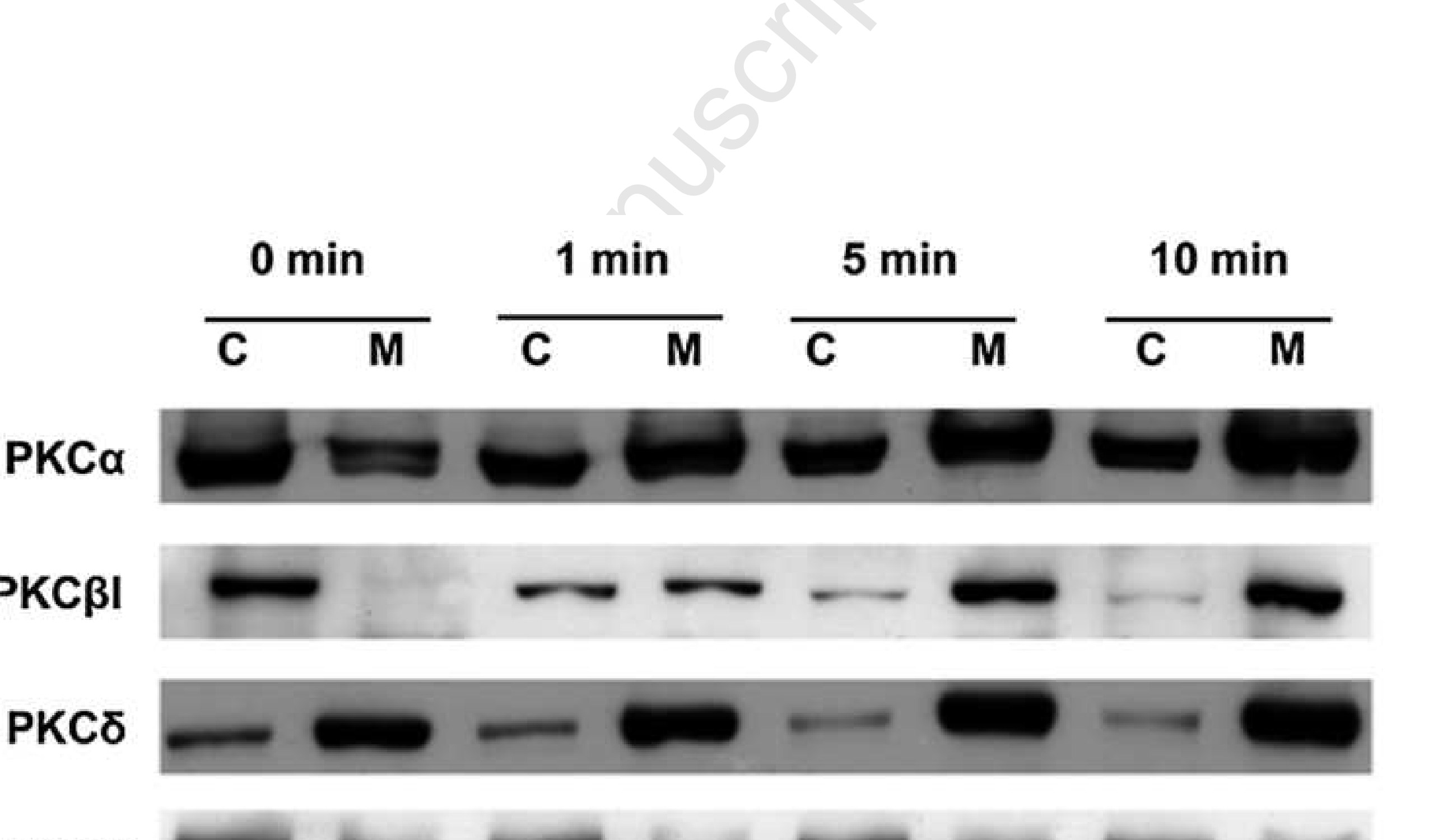

(1)

西
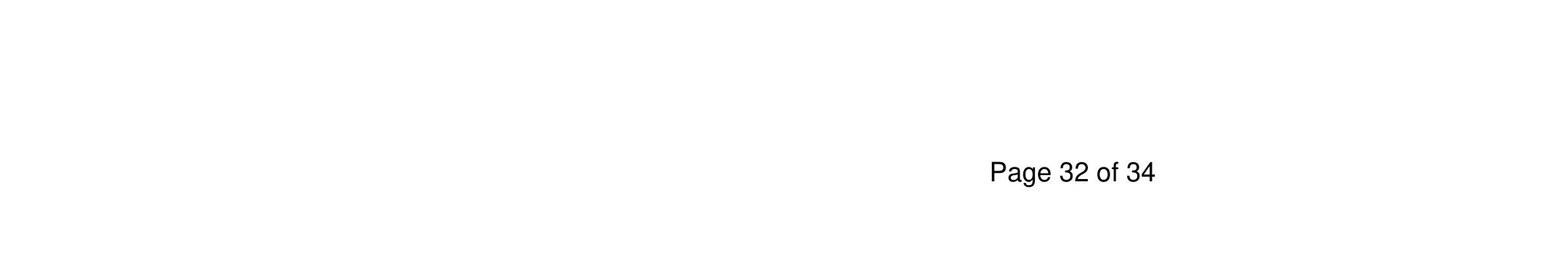
更 .

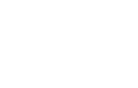

$+$


A

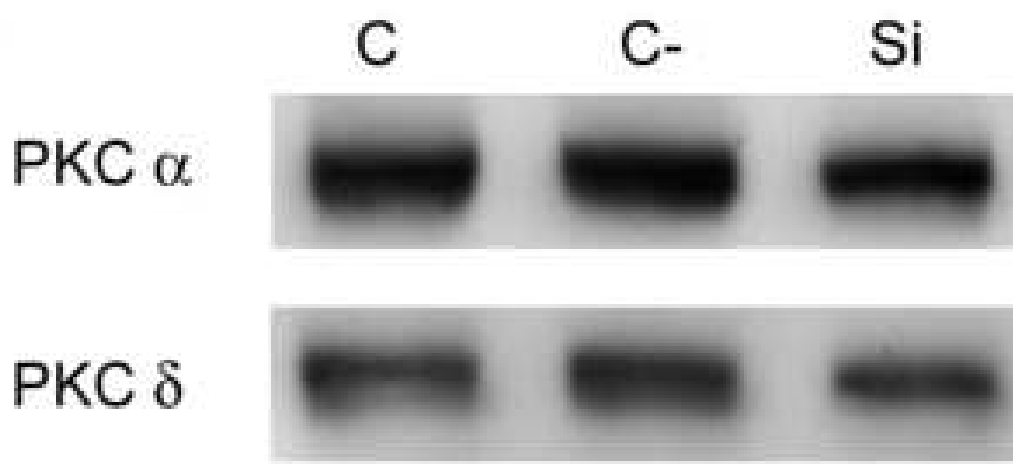

ß-actin

C

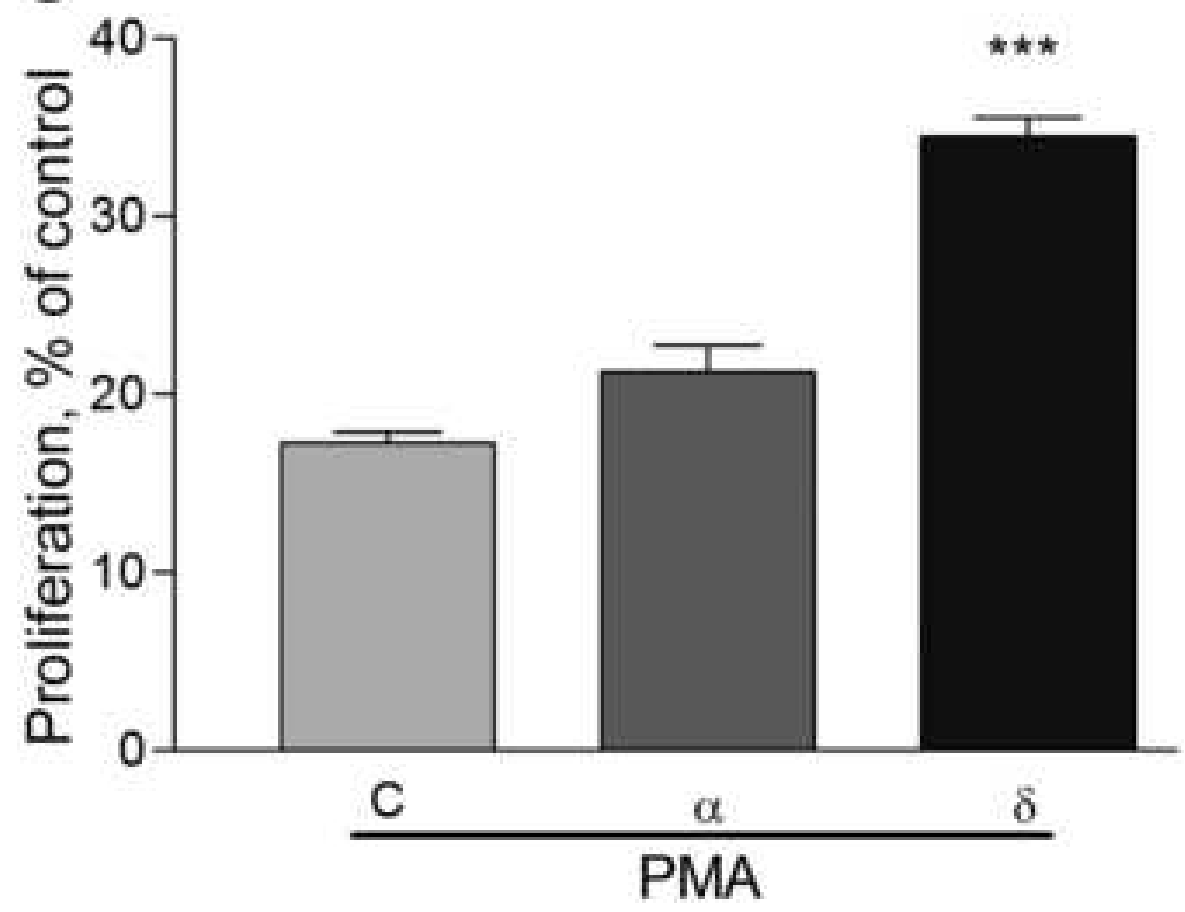

B

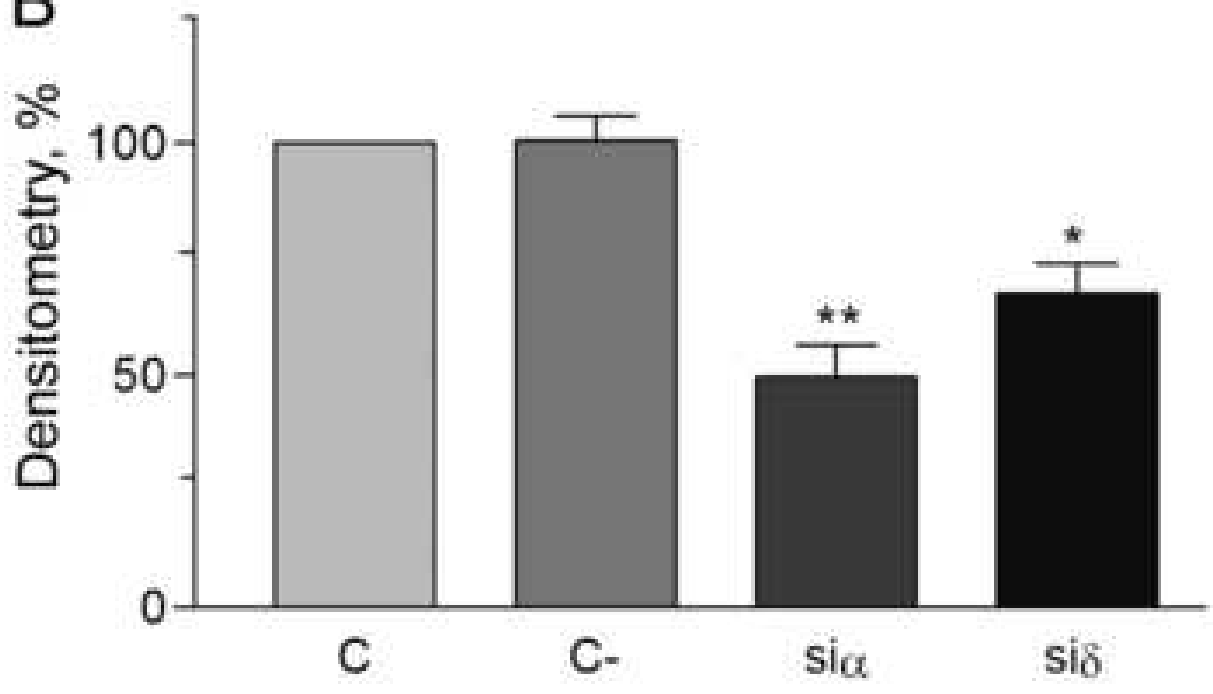

D

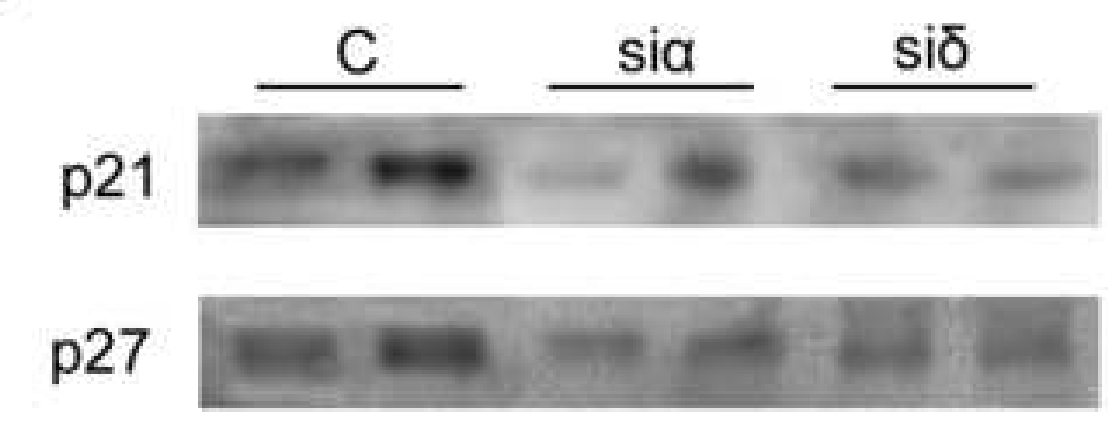

B-actin

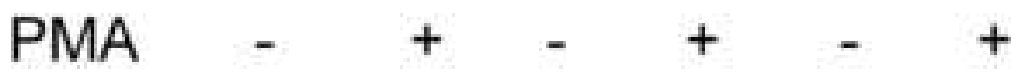


A PMAPK

MAPK
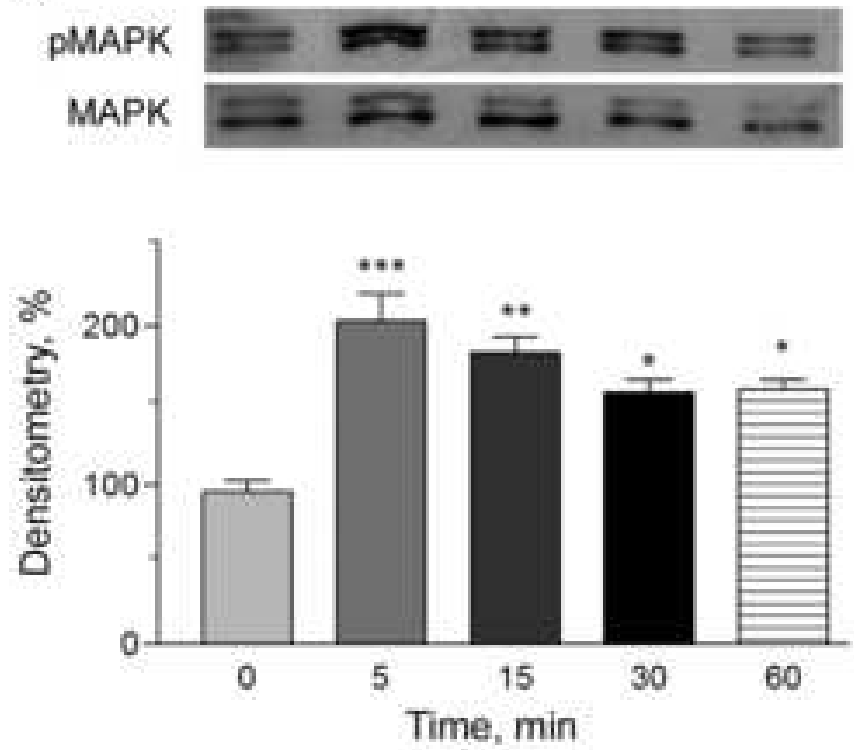

C
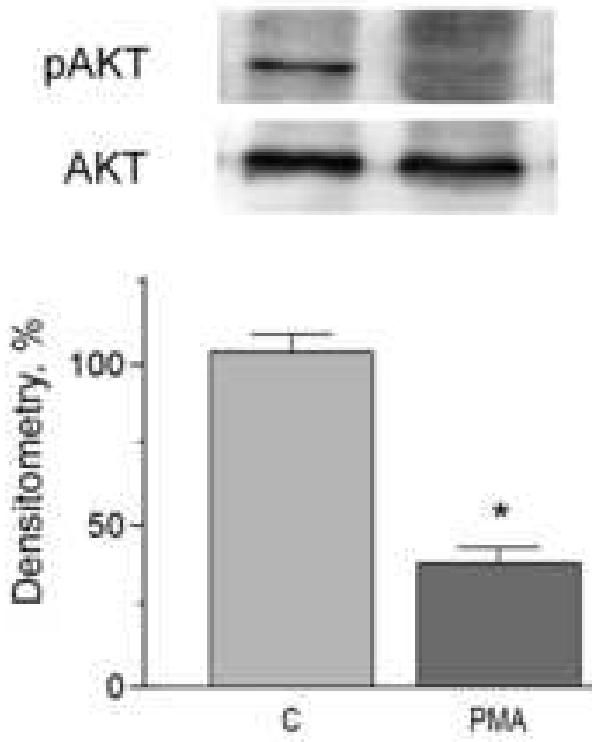

E

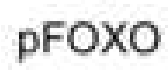

FOXO

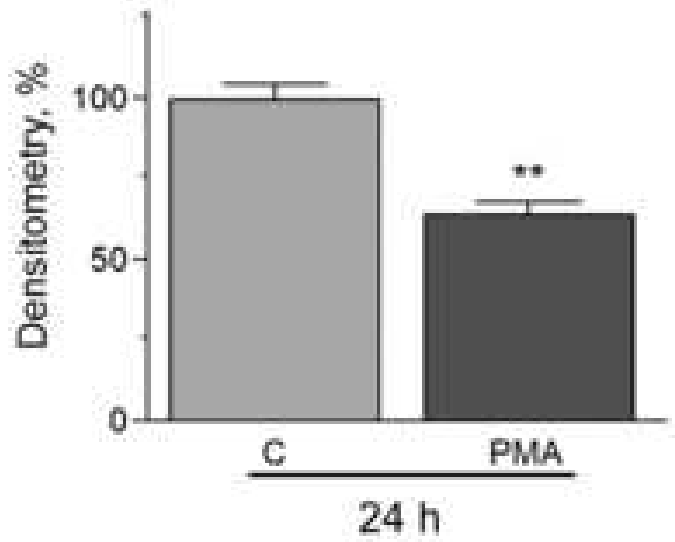

B
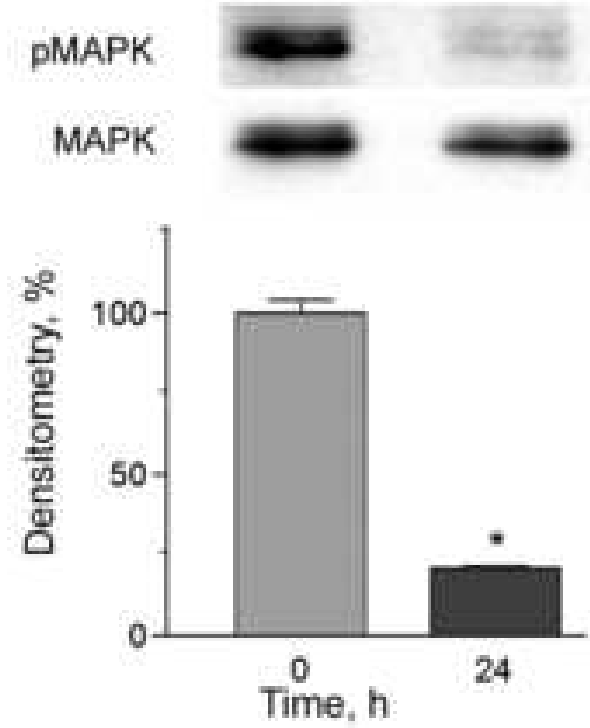

D

\section{pFOXO FOXO}
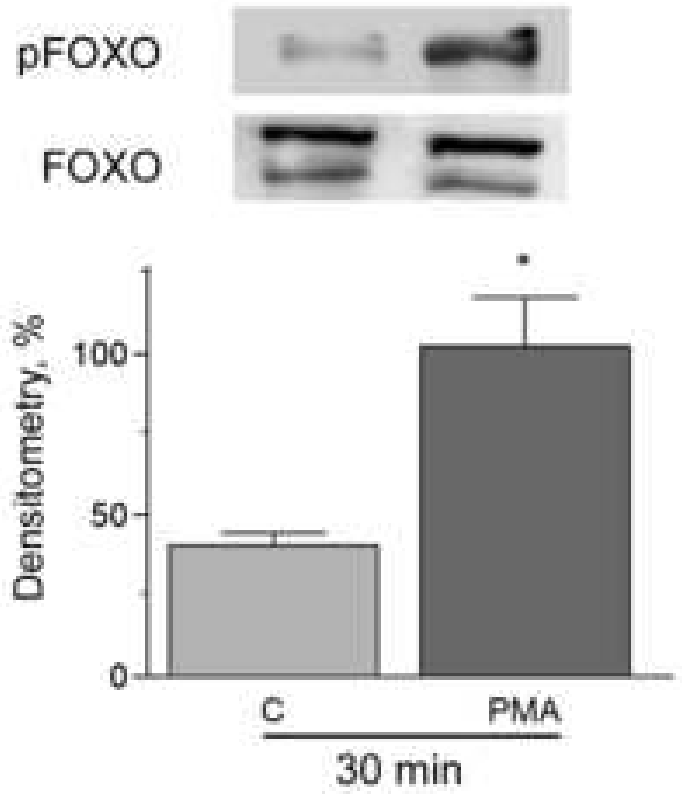